Provided by the author(s) and University of Galway in accordance with publisher policies. Please cite the published version when available.

\begin{tabular}{|c|l|}
\hline Title & $\begin{array}{l}\text { Application of a staged automated calibration methodology to a } \\
\text { partially-retrofitted university building energy model }\end{array}$ \\
\hline Author(s) & Zuhaib, Sheikh; Hajdukiewicz, Magdalena; Goggins, Jamie \\
\hline $\begin{array}{c}\text { Publication } \\
\text { Date }\end{array}$ & 2019-07-10 \\
\hline $\begin{array}{c}\text { Publication } \\
\text { Information }\end{array}$ & $\begin{array}{l}\text { Zuhaib, Sheikh, Hajdukiewicz, Magdalena, \& Goggins, Jamie. } \\
\text { methodology to a partially-retrofitted university building } \\
\text { energy model. Journal of Building Engineering, 26, 100866. } \\
\text { doi: https://doi.org/10.1016/j.jobe.2019.100866 }\end{array}$ \\
\hline $\begin{array}{c}\text { Publisher } \\
\text { Elsevier }\end{array}$ \\
\hline $\begin{array}{c}\text { Link to } \\
\text { version }\end{array}$ & https://doi.org/10.1016/j.jobe.2019.100866 \\
\hline $\begin{array}{c}\text { Item record } \\
\text { Dolisher's//hdl.handle.net/10379/15332 } \\
\text { http://dx.doi.org/10.1016/j.jobe.2019.100866 }\end{array}$ \\
\hline
\end{tabular}

Some rights reserved. For more information, please see the item record link above. 


\title{
Application of a staged automated calibration methodology to a partially- retrofitted university building energy model
}

\author{
Sheikh Zuhaib ${ }^{1,2}$, Magdalena Hajdukiewicz ${ }^{1,2}$, Jamie Goggins ${ }^{1,2, *}$ \\ ${ }^{1}$ Civil Engineering, School of Engineering, College of Science and Engineering, National University of Ireland \\ Galway, Ireland \\ ${ }^{2}$ MaREI Centre, Ryan Institute, National University of Ireland Galway, Ireland \\ ${ }^{*}$ Corresponding Author: email: jamie.goggins@nuigalway.ie (Jamie Goggins), \\ Address: Civil Engineering, School of Engineering, National University of Ireland Galway, Galway, Ireland
}

\begin{abstract}
Deep-retrofit planning for existing buildings demands high accuracy in energy modelling prediction that minimises the gap between actual and simulated scenarios. A large set of interacting variables and uncertainties in energy performance modelling causes perturbations that can be minimised via model calibration. In this work, a novel multi-stage automated calibration methodology was developed using a case study of a partially-retrofitted university building ( $>35$ yrs. old) in Ireland. The methodology enables the analysis of models for Indoor Environmental Quality (IEQ) variables along with energy demand. Due to the higher number of uncertainties in the model, a sensitivity analysis was conducted on the model that is both calibrated and validated as per ASHRAE Guide 14 indices of $\mathrm{Cv}$ (RMSE) and NMBE. The calibration process was automated using the optimisation algorithm NSGA-II with two sets of reference data i.e. monthly utility and hourly indoor air temperature. Results demonstrate that using only utility data for calibration did not result in accurate predictions of the thermal environment; thus, a second stage was used to improve the model prediction giving a $\mathrm{Cv}(\mathrm{RMSE})_{\text {hourly }}=17.0$ to $25.5 \%$ and $\mathrm{NMBE}_{\text {hourly }}=3.6$ to $10.0 \%$ for indoor air temperature across multiple zones. This paper demonstrates an effective staged approach for creating calibrated models of old buildings under high uncertainty that can be used to influence large-scale decision making for retrofits focused on improving indoor environment quality and energy performance.
\end{abstract}

Keywords: Calibration; sensitivity analysis; energy efficiency; building energy model; optimisation; retrofit; simulation 


\section{Introduction}

About $97 \%$ of the buildings in the EU need to be upgraded to meet the 2050 decarbonisation goals [1]. Nondomestic buildings in Europe account for $25 \%$ of the total stock and they have an average energy consumption of $280 \mathrm{kWh} / \mathrm{m}^{2}$ (including all end uses), 40\% higher when compared to the domestic building stock [2]. New buildings represent less than $1.5 \%$ of the total building stock in Europe [3]. Thus, retrofits offer greater opportunities, than building new energy efficient buildings, to meet Europe's emission targets. A large stock of non-domestic buildings was built during the post-war years 1945 to 1985 when building regulations were not stringent and had little focus on energy conservation [4]. The implementation of poor building technology, such as lack of insulation/double-glazing, and high-energy consumption are well-defined characteristics to identify them [5]. Educational buildings account for the largest share of the oldest buildings in the European non-domestic building stock (EU-27) and the majority of these were constructed before 1980 [2]. After the energy crises in the 1970's, the thermal energy efficiency of buildings gained importance in legislations across Europe [5]. A recent focus of EU member states has been to retrofit these existing buildings and improve their energy performance. Most often, due to large floor/envelope area or budget constraints, these buildings are retrofitted in 'piecemeal' or 'single measures' (e.g. double glazing or thermostatic radiator valves (TRVs)) known as 'shallow retrofit' [6] and such interventions are often not supported by detailed investigations and fall short of targets [2]. Building energy models (BEM) are increasingly being used to assess the impact of retrofitting interventions (energy conservation measures/ retrofit measures), which are often not accurate and could lead to wrong decisions [7]. Selection of retrofitting strategies is considered effective with the use of calibrated energy models. However, with old non-domestic buildings ( $>35$ yrs.), it is often challenging to acquire detailed data of the building performance for input to develop accurate energy models [8]. The missing information and lack of measured data lead to uncertainties in creating accurate energy models. Achieving a targeted building energy performance is challenging with these buildings, but of dire need considering the current scenario with low-renovation rates in the EU [5].

A stakeholder study [9] highlighted major gaps in the use of modelling and analysis tools for retrofits in the Irish construction industry. Reliability issues with retrofit solutions showed that building stakeholders (e.g. facility managers, contractors, architects, BER assessors, etc.) regarded variation in measured and actual building performance data as a technical challenge that needs to be addressed in the industry practices. Therefore, the study presented here builds on these findings to account for the large uncertainties and inform decision making through a reliable modelling and calibration approach. 


\section{Literature Background}

In this section, salient literature in relation to building energy model (BEM) development is discussed, including methods for sensitivity analysis and calibration, which has informed the model development methodology presented in this paper (Section 3).

\subsection{Model development}

BEMs help in predicting the potential energy savings in retrofit through analyses of different scenarios. To this purpose, a baseline model is created, for which the results of predicted energy consumption must closely match the actual energy consumption [10]. The geometrical, thermo-physical and operational characteristics have to be defined for the development of building energy models. Such models require input data from detailed building audits and surveys which is often a barrier in developing existing building models. These models can be further developed to identify energy savings for different retrofit measures. Software used for simulation of energy performance, which works on transient relationships of heat transfer [11], include EnergyPlus, DOE-2, e-Quest, ESP-r IDA ICE, IES- VE, TRNSYS. Their use and selection depends on users experience and application criteria [12], [13]. Lee et al. [14] showed that out of 18 freely accessible energy retrofit toolkits, 9 used EnergyPlus as their simulation engine, 2 used DOE-2 and e-Quest together, with the remaining based on empirical data driven and normative methods. EnergyPlus has been utilised for several energy retrofit studies of educational buildings, where the investigation aimed at reliable modelling combined with multi-objective optimisation to determine energy conservation measures for achieving low and near zero-energy standards [15]-[17]. In this work, EnergyPlus is used as the main simulation tool due to its flexible integration with other third-party applications and recommendation by the research community [18]-[20].

\subsection{Sensitivity analysis}

Existing non-domestic building models have large uncertainties involved in the simulation input parameters and, therefore, require uncertainty analysis such as sensitivity analysis [21]. There are certain basic factors that contribute to uncertainty in BEM predictions, such as (i) occupant behaviour, (ii) outdoor weather conditions, (iii) changes due to operation and maintenance, (iv) alterations in indoor environmental conditions, (v) internal heat gains and (vi) building equipment [22]. Due to uncertainty in the input parameters, these models require further tuning of parameters, known as calibration, for achieving a good match with actual performance of the existing building. Often the largest discrepancies occur from the occupant behaviour; therefore, in retrofits, detailed schedules must be developed to reduce the uncertainty [23]. To improve the validity of results from BEM Please cite as: Zuhaib S., Hajdukiewicz M., \& Goggins J. (2019). 'Application of a staged automated calibration methodology to a partially-retrofitted university building energy model'. Journal of Building Engineering, 26, 100866. https://doi.org/10.1016/j.jobe.2019.100866 
simulations, calibration is conducted. However, currently, there are no standard frameworks to address uncertainty in BEM [24]. A range of sources of uncertainty was determined by Heo et al. [25] when carrying out energy retrofit analysis on buildings. The relevance of calibrated models in the retrofit analysis has been highlighted in research for decision making [26].

Sensitivity analysis is often a pre-requisite to the calibration process and is used to minimise the uncertainty [27][29]. It determines the contribution of the individual simulation parameters to the total energy performance of the BEM. Sensitivity analysis methods are classified into local methods (computationally fast with reduced shape and space for input parameters around a base case) [15], [30]-[33] and global methods (regression, screen, variancebased and meta-models that examine the influence of uncertain parameters over a whole parameter range) [15], [34]-[40]. The choice of methods depends on several factors such as time, cost, research purpose, familiarity with methods and number of input variables. Local sensitivity analysis has been used previously in research with BEMs, to provide building designers an overview of impact by adjusting a focus parameter on indoor environment and energy performance prior to building construction [41]. Global sensitivity analysis methods are popularly known as screening based methods that identify the least important inputs in the building energy simulation that can be fixed to a value without significantly affecting the output from the model [42]. Different properties of sensitivity analysis methods include (i) scale and shape of Probability Density Function (PDF), (ii) multidimensional averaging, (iii) model independency, and (iv) relative computational time with a description of their strength and weaknesses. A widely adopted global screening method used for sensitivity analysis in building simulation is the Morris method, as it provides a qualitative measure of the effect of each parameter on model outputs [43]. In sensitivity analysis, a large parameter set must be identified and undergo screening before calibration. Example software that has been recommended by researchers for sensitivity analyses in building performance analysis include SimLab and R [40].

\subsection{Calibration}

Calibration is a 'manual, iterative and pragmatic intervention' to BEM [44]. Calibration can be based on special tests and analytical methods/ procedures. BEM calibration is also referred to as an over parameterised process that has immense interdependencies with input variables representing the complexity of building systems [22]. Generally, in building energy modelling, calibration is done by comparing measured/metered data with simulated data and achieving the acceptance criteria outlined by ASHRAE Guide 14 [45] and IMPVP [46]. A review of several studies has highlighted different methods of calibration of BEMs being adopted in the industry and 
research [7]. Graphical techniques are rarely used by modellers for calibration, as it only allows visualisation of results between simulated and actual data [47]. Manual calibration approaches often work with a limited number of parameters, and are highly time consuming as compared to automated approaches (optimisation techniques and alternative modelling techniques) requiring advanced knowledge of building simulation [48]. Several optimisation approaches are being used by researchers to automate the calibration process such as genetic algorithm (GA), particle-swam optimisation (PSO) and Bayesian optimisation (BO) [29], [37], [49], [50] have been found to be effective and efficient in solution search. Among GA, NSGA-II has proven its capabilities in optimisation using a natural selection method and has been a popular choice of researchers for single or multi-objective functions [51]-[53]. It works by maintaining a population of individuals and selection of the fittest to move on to the next generations. The diversity of individuals is maintained by crossover and mutation. The NSGA-II works on a nondominated sorting and ranking process of individuals maintaining the spread of solutions and converges into a non-dominated front [51]. Crowding distance is calculated for each solution to maintain the spread along the front. Most of the BEM tools generally do not provide native retrofit optimisation, therefore, third-party optimisation applications are generally used for calibration automation purposes [54].

Model calibration is completed by validating the simulation results with the standard acceptance criteria [46]. The energy model is calibrated based on the resultant parameters obtained from the sensitivity analysis. The parameters are adjusted during the iterative/automated process of calibration. The model is considered calibrated when the acceptable criteria have been met. The acceptable tolerances as per ASHRAE Guideline 14 [45] and IMPVP [46] are given in Table 1.

Table 1 Acceptable tolerances for validation of building energy models

\begin{tabular}{llcc}
\hline Calibration type & Index & ASHRAE Guide 14 & IMPVP $^{\mathbf{1}}$ \\
\hline Monthly & NMBE ${ }_{\text {Monthly }}$ & $5 \%$ & $20 \%$ \\
& Cv (RMSE) Monthly & $15 \%$ & - \\
\hline Hourly & NMBE ${ }_{\text {Hourly }}$ & $10 \%$ & $5 \%$ \\
\multicolumn{2}{l}{ Cv (RMSE) Hourly } & $30 \%$ & $20 \%$ \\
\hline${ }^{1}$ Lower values indicate better calibration; & \\
Acronyms: NMBE: normalised mean bias error, Cv(RMSE): Coefficient of variation of the root mean squared error \\
\hline
\end{tabular}

The level of calibration is dependent on the availability of the data and all models should be calibrated using at least monthly data, but ideally more frequent data [45]. A range of data for calibration can be obtained from the actual building, from physical surveys, interviews, building audits, building energy management systems, and other measurements. Therefore, it is important to classify the levels of calibration based on the available data [7]. 
Different levels of calibration are proposed in literature according to the building information available are shown in Table 2 [27], [55], [56]. Level 1 is the basic calibration level without any details of building operation. Level 2 approach requires site verification using as-built data. Level 3 is based on detailed audit and spot measurements. Level 4 and 5 are the most detailed calibration levels where data is collected using data loggers with Level 5 requiring long-term monitoring. The stages of calibration can be determined by combining the different levels of building data available depending on the complexity and details for which the calibration is conducted.

Table 2 Calibration levels based on the available building information [55]

\begin{tabular}{|c|c|c|c|c|c|c|}
\hline \multirow{2}{*}{$\begin{array}{l}\text { Calibration } \\
\text { levels }\end{array}$} & \multicolumn{6}{|c|}{ Building input data available } \\
\hline & $\begin{array}{l}\text { Utility bills } \\
\text { (one year) }\end{array}$ & $\begin{array}{c}\text { As-built } \\
\text { data }\end{array}$ & $\begin{array}{l}\text { Site visit or } \\
\text { inspection }\end{array}$ & $\begin{array}{c}\text { Detailed } \\
\text { audit }\end{array}$ & $\begin{array}{l}\text { Short-term } \\
\text { monitoring }\end{array}$ & $\begin{array}{l}\text { Long-term } \\
\text { monitoring }\end{array}$ \\
\hline Level 1 & o & o & & & & \\
\hline Level 2 & $\circ$ & o & o & & & \\
\hline Level 3 & o & o & o & o & & \\
\hline Level 4 & o & o & 0 & o & o & \\
\hline Level 5 & o & o & o & 0 & o & o \\
\hline
\end{tabular}

After reviewing several studies, Coakley et al. [48] indicated that empirical model calibration methods can reduce the gap between the actual and simulated data patterns and improve calibration feasibility. One of the most significant parameters that could affect the prediction of energy consumption in BEM is the accuracy of occupancy data and plug loads [57], as these are related to behaviour of occupants. These parameters should be first adjusted based on measured data in model calibration, which is generally opposite to the traditional method described in the standards to start calibration with energy utility bills or data [27].

The main objective of this study is to present a methodology for the calibration of an energy model combined with sensitivity analysis of a partially retrofitted non-domestic building ( $>35$ yrs. old), which can subsequently be used to investigate further retrofit opportunities, achieve energy savings and improved comfort. There is a lot of research on building energy model calibration [14]; yet it is not effectively developed for the purpose of retrofit application of old non-domestic buildings and the same is presented in this research. A field study conducted by the authors [58] on indoor environmental quality (IEQ) is used as a case study to focus on the use of calibrated models for IEQ studies. In further sections, a brief description of the case study is presented including initial building energy model and sensitivity analysis. Further, the calibration is carried out using the reference data from the case study. 


\section{Methodology}

The main objective of this study is to present an automated optimisation-based calibration methodology that can be utilised by researchers and professionals to calibrate building energy models for retrofit of non-domestic buildings for prediction of energy demand and IEQ performance. The calibration methodology was developed based on the available literature and advancements in calibration [56] and considering the requirement of reduced complexity, computation time, effort and expertise, making it more robust for general users. The methodology is divided into four main parts as shown in Figure 1: (a) model preparation, (b) sensitivity analysis, (c) staged automated calibration and validation, and (d) additional validation.

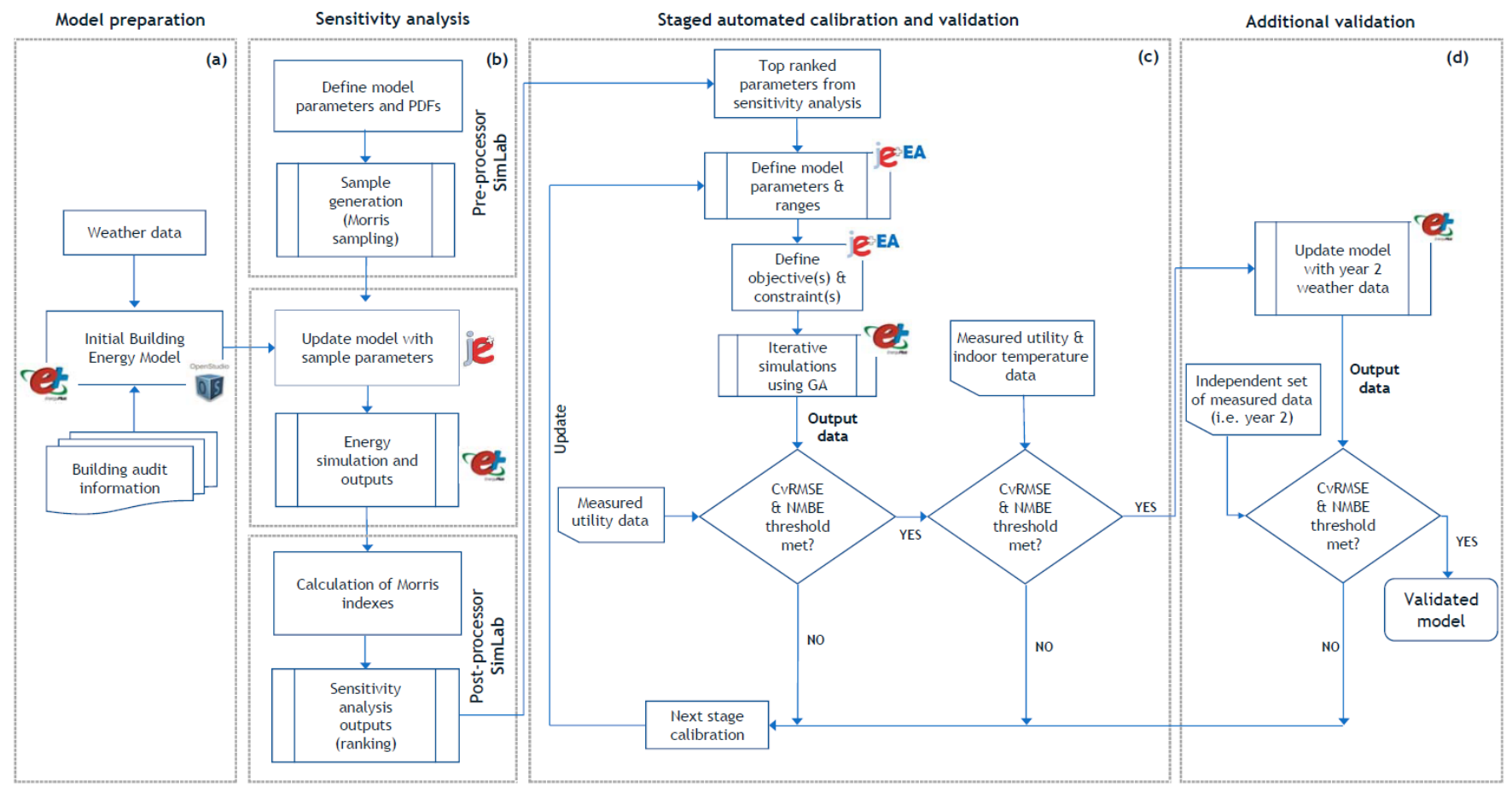

Figure 1 Calibration methodology

As illustrated in Figure 1(a), the calibration methodology begins with the development of an initial building energy model (BEM) of the case study building. To develop the BEM, the data was collected from building audits, construction specifications, technical surveys and local weather station. These are discussed in Section 4.1 and 4.2 in detail. The environment of OpenStudio ${ }^{\circledR} 2.4 .0$ [59] coupled with EnergyPlus ${ }^{\circledR} 8.8 .0$ [19] was used in the preparation of the BEM.

Prior to calibration, a sensitivity analysis was conducted on the input parameters of the BEM identified as most influential on energy consumption based on the literature [35], [60], [61] and condition of the existing building. 
The sensitivity analysis also minimises the number of parameters required for calibration to achieve better accuracy. The initial energy model was used to determine the sensitive input parameters for calibration using Morris method with SimLab ${ }^{\circledR} 4.0$ [62] and jEPlus ${ }^{\circledR}$ v1.7 [63], as shown in Figure 1(b). The input parameters were ranked based on the Morris indexes to be used in calibration. The complete process of sensitivity analysis has been described in Section 4.3 for the case study.

After the sensitivity analysis, the top ranked parameters were selected for tuning the model during calibration with defined lower and upper bounds. The calibration was conducted using NSGA-II optimisation (jEPlus + EA ${ }^{\circledR}$ v1.7.6 coupled with EnergyPlus ${ }^{\circledR}$ 8.8.0) as shown in Figure 1(c). The program jEPlus+EA [63] was used for automating the process and running the optimisation algorithm on the parameters to achieve the calibration acceptance criteria by validating them against the statistical indices as presented in Section 2.3. EnergyPlus [19] was used for batch simulations within the interface. A population (number of solutions evaluated in each iteration) of 30 was chosen due to available the CPU (6 cores, 12 threads) and a large number of calibration parameters (25). A higher number of generations improves the accuracy of the solutions [64]; therefore, maximum generations were set to 200 for both the stages. A high value of $1(100 \%)$ was taken for the crossover rate and a lower mutation rate of $0.2(20 \%)$ was employed to avoid randomisation by the algorithm. Convergence was chosen as the stopping criteria of the optimisation algorithm. Convergence stability percentage (based on the mean and standard deviation of outputs) was set to $5 \%$ and when the iterations reached the desired level of stability the optimisation converged (population stable with regard to previous one). The automation allowed simultaneous simulations to be run, resulting in reduction in time and effort required for calibration as compared to a manual approach. In this study, calibration consolidates the levels of input information divided into two-stages to outline the impact of different measured datasets (utility and temperature) on calibration accuracies [65].

In the first-stage, the model corresponds to Level 1-4, where the optimisation objective functions were set to minimisation of $\mathrm{Cv}(\mathrm{RMSE})_{\text {Monthly }}$ and $\mathrm{NMBE}_{\text {Monthly }}$ between measured and simulated data for both heating and electrical monthly energy consumption. The model input values were altered automatically based on value constraints during automated optimisation. The actual monthly utility data of the case study building was available for two years. The first year of data was used in the first-stage, as per the standard practice of energy model calibration to assess the energy performance [45]. Smaller interval (hourly) utility data can also be used in the first-stage for achieving better accuracy. However, utilising detailed measured utility data may not ensure accurate predictions of the indoor environment variables; therefore, predicted indoor temperature from the model was Please cite as: Zuhaib S., Hajdukiewicz M., \& Goggins J. (2019). 'Application of a staged automated calibration methodology to a partially-retrofitted university building energy model'. Journal of Building Engineering, 26, 100866. https://doi.org/10.1016/j.jobe.2019.100866 
compared to measured data [66]. If the error does not meet the acceptance criteria, further stages may be used for tuning the model to reduce the differences in measured and simulated data indoor environment variables, while minimising the error for energy consumption. After achieving the convergence, the optimisation process was completed, and the simulation results were plotted to obtain a Pareto frontier that provided the most optimal set of solutions (calibrated input parameters).

Hence, based on the above criteria, in the second-stage, the model represents Level 1-5, where the optimisation objective functions were set to minimisation of $\mathrm{Cv}(\mathrm{RMSE})_{\text {Hourly }}$ and $\mathrm{NMBE}_{\text {Hourly }}$ between measured and simulated hourly indoor air temperature data of each zone with constraints set on indices for heating and electrical energy consumption to be within the threshold values. Using a multi-staged approach can be useful for controlled calibration using multiple datasets, especially for IEQ based studies.

If the acceptance criteria are not met in the first stage, then the user updates the model until the criteria are met for the first variable (e.g. energy demand). Once the acceptance criteria are met for the initial variable then the user employs a second (or multiple additional) measured data sets (e.g. air temperature, $\mathrm{CO}_{2}$, humidity) in the subsequent stage to achieve the acceptance criteria for other variables (e.g. air temperature, $\mathrm{CO}_{2}$, humidity) based on the purpose of calibration. The corresponding indices $\mathrm{Cv}(\mathrm{RMSE})[\%]$ and NMBE [\%] for both stages were calculated as per ASHRAE Guideline 14 [45] to achieve the acceptance criteria for calibration in two-stages. An additional validation was also conducted using an independent set of measured weather data, as outlined in Figure 1(d). The hardware of the CPU used in the analysis of this research had the following configurationIntel ${ }^{\circledR}$ Xeon ${ }^{\circledR}$ X5690@3.47 GHz, RAM, 24.0 GB.

\section{Case study}

The case study building is an education building with a total area of $1073 \mathrm{~m}^{2}$ located in the campus of the National University of Ireland, Galway in Ireland and housing an academic department. It is connected to the main building from the South-East end and located beside a river on the North-East. The building was built during the 1970s and was partially retrofitted in 2005. It has two floors with $2.71 \mathrm{~m}$ high false-ceiling and a plenum space of $0.69 \mathrm{~m}$ (ground floor) and $1.41 \mathrm{~m}$ (first floor). It comprises of single occupant offices, post-graduate students' rooms, conference rooms, laboratories and lecture rooms. There are 25 occupied zones in the building (Figure 2). A detailed field study of the building was conducted previously [58], which highlighted the conditions of the existing building with respect to IEQ (thermal, visual and acoustic comfort) and requirements to retrofit the building. 
Along with the IEQ surveys, detailed surveys and interviews were also conducted as a part of the building energy audit for occupancy, lighting, equipment and energy use. The monitoring period for that study was from June 2016 to May 2017.

\subsection{Data collection}

The building is occupied throughout the year with weekends generally non-working, but the lecture rooms are only occupied in accordance with the teaching semester schedule (including summer/ winter break and holidays). The Buildings and Estates office provided individual room booking data for lecture rooms, conference rooms and laboratories. All other occupancy schedules were determined through questionnaires with the occupants. The building is primarily heated by baseboard heating units fitted with thermostatic radiator valves (TRVs) in every room. The hot water for heating is supplied through a central district heating system with integrated combined heat and power (CHP) unit. The flow temperature is user-adjustable, and supply is controlled by a variable speed pump managed by the facility manager based on the weather conditions. A schedule of flow temperatures was available from the built-in data loggers. Due to the absence of automatic room thermostats, there was high uncertainty in the usage of TRVs and their schedules were prepared based on the information from occupants. Both the ground and first floor zones had different valves to control the heating supply. The heating system schedule for the building was determined based on the operation schedule of the CHP adjusted by the facility manager. There was a lack of local controls leading to heating of the building when not required. The heating system schedule provided by the Buildings and Estates Office is shown in Table 3.

Table 3 Heating system schedule for the case study building

\begin{tabular}{|c|c|c|c|c|c|c|c|}
\hline Ventilation type & $\mathrm{NV}$ & & & & $\mathrm{H}$ & & $\& \mathrm{H}$ \\
\hline Heating period & -- & $15 / 10 /$ & $1 / 11 / 16$ & $1 / 12 / 1$ & $3 / 02 / 17 *$ & $1 / 03 /$ & $14 / 05 / 17$ \\
\hline \multirow{2}{*}{ Daily heating schedule } & -- & $\begin{array}{c}\text { Mon- } \\
\text { Sat }\end{array}$ & Sun & $\begin{array}{l}\text { Mon- } \\
\text { Sat }\end{array}$ & Sun & $\begin{array}{c}\text { Mon- } \\
\text { Fri }\end{array}$ & Sat-Sun \\
\hline & -- & $\begin{array}{l}08: 00- \\
22: 00\end{array}$ & $\begin{array}{l}\text { 08:00- } \\
13: 00\end{array}$ & $\begin{array}{l}08: 00- \\
22: 00\end{array}$ & $\begin{array}{l}\text { 08:00- } \\
13: 00\end{array}$ & $\begin{array}{l}08: 00- \\
17: 00\end{array}$ & $\begin{array}{l}08: 00- \\
13: 00\end{array}$ \\
\hline
\end{tabular}

The building is only naturally ventilated throughout the year. The building envelope is composed of a singleglazing system (without thermal breaks) and double-glazing system (with thermal breaks) fitted with operable windows in the original and retrofitted façade, respectively (Figure 2 and 3). The tilted windows in the glazing 
system are operated by occupants for natural ventilation. The natural ventilation rate considered in the calculations is based on the results of the field-study [58]. Blower door tests were also conducted during the field-study [58] to determine the infiltration rate of 2.3 $\mathrm{ACH}$ and 3.0 $\mathrm{ACH}$ for retrofitted and non-retrofitted zones, respectively.

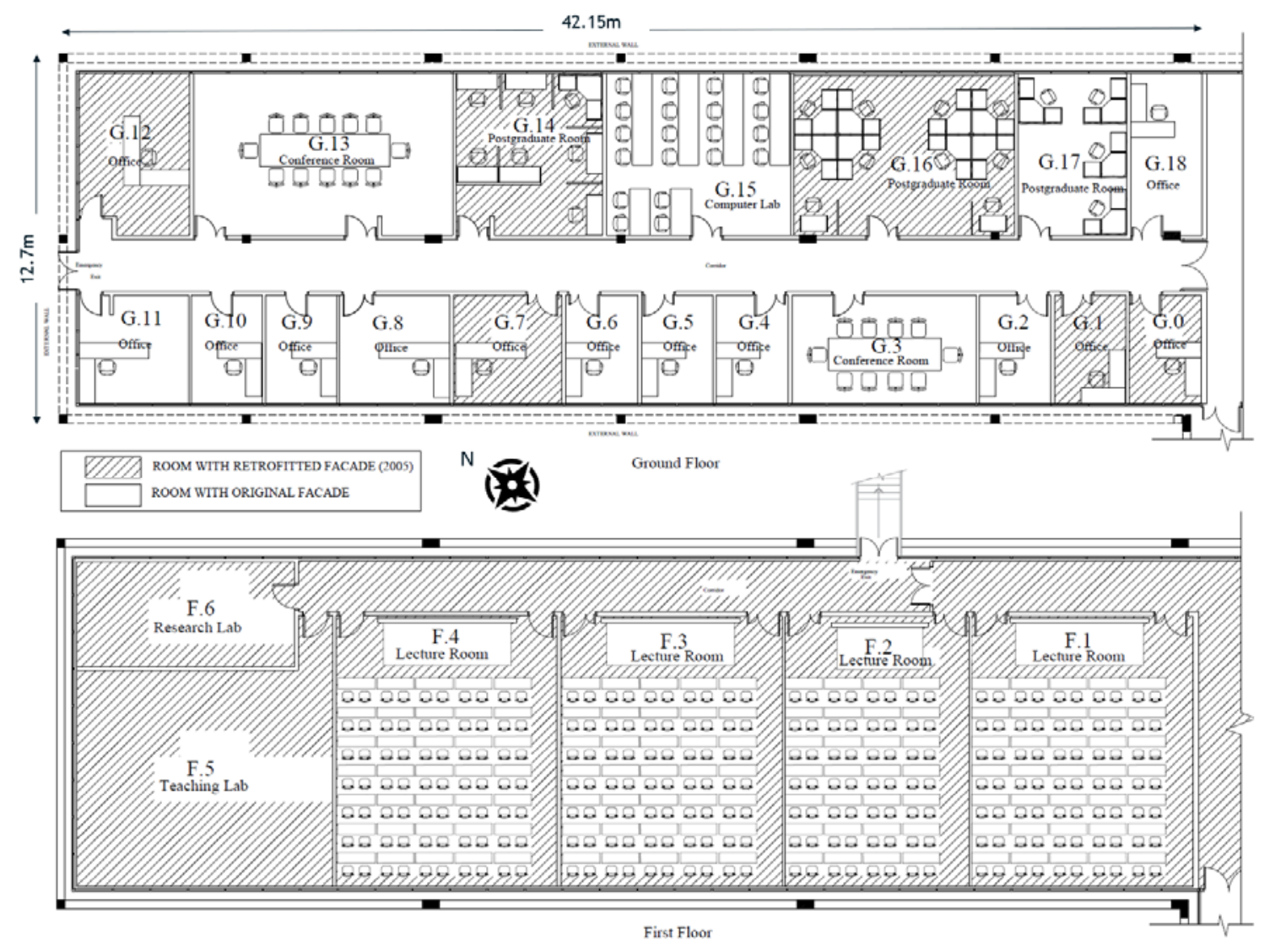

Figure 2 Floor plans of the case study building [58]

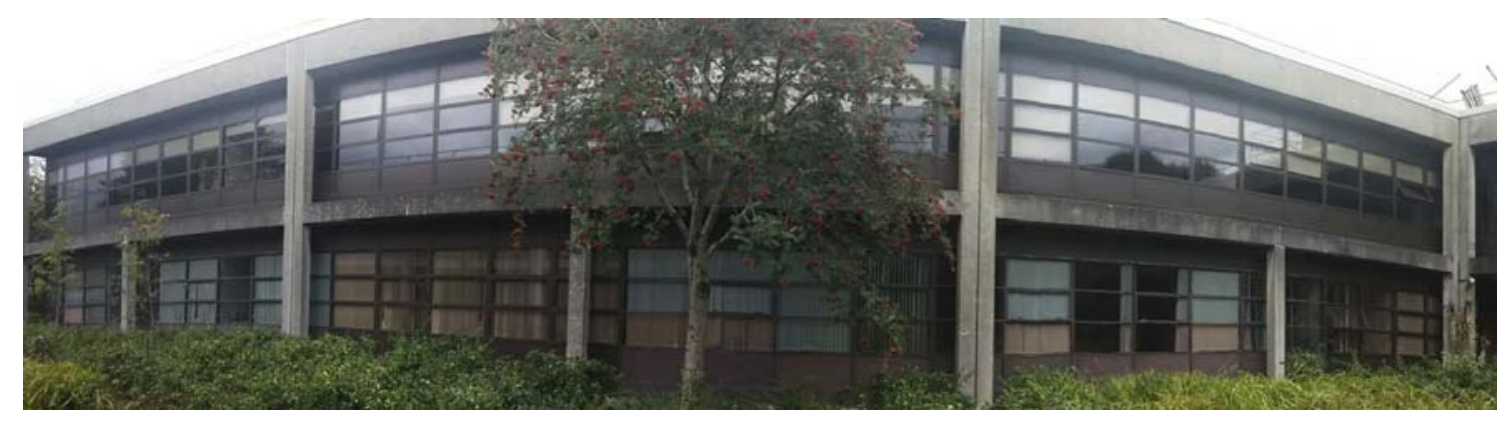

Figure 3 Panoramic view of the building

Other than natural light through the windows, the main source of lighting is artificial lighting with recessed luminaries T8 (parabolic louver and non-vented) with $0.30 \%$ of the convective fraction. Daylight and glare are controlled via indoor vertical blinds when there are sunny days. The lighting loads were calculated individually for all zones and the lighting schedules were prepared based on occupants' survey and interviews. Equipment Please cite as: Zuhaib S., Hajdukiewicz M., \& Goggins J. (2019). 'Application of a staged automated calibration methodology to a partially-retrofitted university building energy model'. Journal of Building Engineering, 26, 100866. https://doi.org/10.1016/j.jobe.2019.100866 
loads were measured and calculated individually using a watt-meter for each zone based on the equipment present, and their operation schedules were prepared from the information collected in interviews. Convective fractions for equipment were calculated for individual equipment based on literature [67]-[69]. Uncertainty can be attributed to the use of equipment and lighting by the occupants and the schedules cannot represent the exact usage for every hour in the schedule, but overall may represent a good match.

In the previous field study, detailed surveys and interviews were also conducted along with short and long-term monitoring to assess the IEQ [58]. Monthly heating and electrical energy metered data were made available through the Buildings and Estates Office for the period of one year (June 2016- May 2017) and were used in the calibration process. Detailed indoor air temperature data were also collected from June 2016 to May 2017 during the IEQ evaluation along with other physical variables. Therefore, the hourly indoor temperature data was also used for calibrating the model in this study. A local weather station [70] is located on the roof of the case study building (N53 $16^{\prime} 47^{\prime \prime}$ W9 03 '37') and recorded weather data at one-minute intervals. The recorded parameters included dry bulb air temperature, relative humidity, barometric pressure, total and diffuse solar irradiation, wind speed, wind direction and rainfall. The collected weather data for Galway was used in the building energy model for simulations using values at hourly time-steps.

\subsection{Initial building energy model}

The initial BEM of the case study building was created using OpenStudio (GUI for EnergyPlus) as depicted in Figure 4. The initial model was prepared based on the building energy audit, design specification, and technical surveys [58]. The detailed input specifications of the building model (25 zones) including the building components (see Table 4), schedules (occupancy, lighting equipment), loads (equipment and lighting) (see Table 5) and heating system were as per the building energy audit (Section 4.1). Partial-retrofit of the building posed a few challenges in modelling the individual zones having different façade composition (original and retrofitted) and infiltration rates on both the floors. 


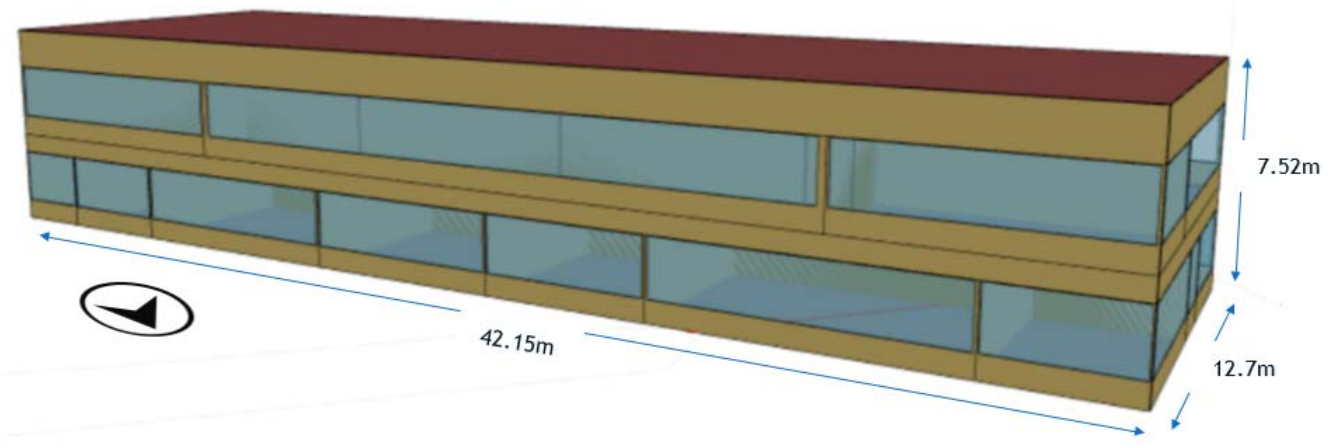

Figure 4 OpenStudio model of the case study building

The building construction input details used as model inputs are given in Table 4 and were reported according to the technical documentation. Infiltration rates used were based on the blower door test [58]. The minimum indoor temperature for natural ventilation to occur was set to $21^{\circ} \mathrm{C}$ in the model. Temperature set point data was available through interviews with the occupants, but this parameter was highly variable due to occupants' behaviour and independent adjustments and was based on their experience and best estimates. The temperature set point was based on the range estimated from the TRV setting (e.g. * $1,2,3,4,5)$ i.e. $20-24^{\circ} \mathrm{C}$. The building did not have any external shading device and had only internal blinds that were modelled. Since the neighbouring buildings did not impose any significant mutual shading throughout the year, therefore, were not modelled. A constant temperature boundary condition was applied for each month of the year for the outside surface temperature for all surfaces adjacent to ground in OpenStudio and construction of earth layers was excluded to reduce complexity [71] in the model.

Table 4 Input parameters of main building components [58]

\begin{tabular}{|c|c|c|c|c|c|c|}
\hline Component & 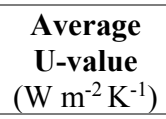 & Layers (thickness) & $\begin{array}{l}\text { Conductivity } \\
\left(\mathrm{W} \mathrm{m}^{-1} \mathrm{~K}^{-1}\right)\end{array}$ & $\begin{array}{l}\text { Density } \\
\left(\mathrm{kg} \mathrm{m}^{-3}\right)\end{array}$ & $\begin{array}{l}\text { Specific heat } \\
\text { capacity } \\
\left(\mathrm{J} \mathrm{kg}^{-1} \mathbf{K}^{-1}\right)\end{array}$ & Remarks \\
\hline Roof & 0.54 & $\begin{array}{l}\text { Roof membrane }(9.5 \mathrm{~mm}) \\
\text { Rockwool insulation }(88 \mathrm{~mm}) \\
\text { Metal Decking }(1.5 \mathrm{~mm})\end{array}$ & $\begin{array}{c}0.16 \\
0.049 \\
45.06\end{array}$ & $\begin{array}{l}1121 \\
265 \\
7680\end{array}$ & $\begin{array}{l}1460 \\
836 \\
500\end{array}$ & - \\
\hline Ceiling & 3.14 & Mineral fibre board $(19 \mathrm{~mm})$ & 0.06 & 368 & 590 & All zones \\
\hline Exterior walls & 0.26 & $\begin{array}{l}\text { Metal panel }(5 \mathrm{~mm}) \\
\text { Board insulation }(50 \mathrm{~mm}) \\
\text { Rockwool insulation }(100 \mathrm{~mm}) \\
\text { Plasterboard }(12.5 \mathrm{~mm})\end{array}$ & $\begin{array}{c}45.28 \\
0.03 \\
0.049 \\
0.16 \\
\end{array}$ & $\begin{array}{l}7824 \\
43 \\
265 \\
800\end{array}$ & $\begin{array}{l}500 \\
1210 \\
836 \\
1090 \\
\end{array}$ & All zones \\
\hline Interior walls & 2.57 & $\begin{array}{l}\text { Plaster }(20 \mathrm{~mm}) \\
\text { Concrete block }(100 \mathrm{~mm}) \\
\text { Plaster }(20 \mathrm{~mm})\end{array}$ & $\begin{array}{l}0.16 \\
0.72 \\
0.16\end{array}$ & $\begin{array}{l}600 \\
1920 \\
600 \\
\end{array}$ & $\begin{array}{l}1000 \\
840 \\
1000\end{array}$ & All zones \\
\hline $\begin{array}{l}\text { Single glazing } \\
\text { (metal frame } \\
\text { with no } \\
\text { thermal break) }\end{array}$ & 5.79 & -- & -- & & & $\begin{array}{l}\text { Non- } \\
\text { retrofitted } \\
\text { zones }\end{array}$ \\
\hline $\begin{array}{l}\text { Double glazing } \\
\text { (metal frame }\end{array}$ & 1.89 & -- & -- & & & $\begin{array}{l}\text { Retrofitted } \\
\text { zones }\end{array}$ \\
\hline
\end{tabular}

Please cite as: Zuhaib S., Hajdukiewicz M., \& Goggins J. (2019). 'Application of a staged automated calibration methodology to a partially-retrofitted university building energy model'. Journal of Building Engineering, 26, 100866. https://doi.org/10.1016/j.jobe.2019.100866 


\begin{tabular}{|c|c|c|c|c|c|c|}
\hline $\begin{array}{l}\text { with thermal } \\
\text { break) }\end{array}$ & & & & & & \\
\hline \multirow[t]{2}{*}{ First floor slab } & \multirow{2}{*}{4.67} & Linoleum tile ( $8 \mathrm{~mm})$ & 0.19 & 1200 & 1470 & \multirow[t]{2}{*}{-} \\
\hline & & Concrete dense $(300 \mathrm{~mm})$ & 1.4 & 2100 & 840 & \\
\hline \multirow{4}{*}{$\begin{array}{l}\text { Ground floor } \\
\text { slab }\end{array}$} & \multirow{4}{*}{2.57} & Linoleum tile $(8 \mathrm{~mm})$ & 0.19 & 1200 & 1470 & \multirow[t]{4}{*}{-} \\
\hline & & Screed $(75 \mathrm{~mm})$ & 0.41 & 1200 & 840 & \\
\hline & & $\mathrm{DPC}(3 \mathrm{~mm})$ & 0.14 & 1200 & 1000 & \\
\hline & & Concrete dense $(200 \mathrm{~mm})$ & 1.4 & 2100 & 840 & \\
\hline Doors & 2.97 & Wooden panel (25 mm) & 0.15 & 608 & 1630 & All zones \\
\hline $\begin{array}{l}\text { Shading } \\
\text { (Vertical } \\
\text { blinds) }\end{array}$ & - & Slat (1.5mm) & 0.02 & - & - & All zones \\
\hline
\end{tabular}

A detailed summary of loads and internal gains used in the initial building energy model are given in Table 5, together with individual zone information highlighting the retrofitted and non-retrofitted status.

Table 5 Summary of loads and internal gains

\begin{tabular}{|c|c|c|c|c|c|c|c|c|}
\hline oom & Type of room & $\begin{array}{l}\text { Glazing \& } \\
\text { Orientation }\end{array}$ & Status & $\begin{array}{l}\text { Area } \\
\left(\mathrm{m}^{2}\right)\end{array}$ & $\begin{array}{l}\text { Occupant } \\
\text { load }\left(\mathrm{m}^{2}\right. \\
\left.\text { person }^{-1}\right)\end{array}$ & $\begin{array}{c}\text { Lighting } \\
\text { load } \\
\left(\mathrm{W} \mathrm{m}^{-2}\right)\end{array}$ & $\begin{array}{c}\text { Equipment } \\
\text { load } \\
\left(\mathrm{W} \mathrm{m}^{-2}\right)\end{array}$ & $\begin{array}{c}\text { Additional } \\
\text { equipment } \\
\text { (W m }{ }^{-2} \text { ) }\end{array}$ \\
\hline
\end{tabular}

\begin{tabular}{|c|c|c|c|c|c|c|c|c|}
\hline G.0 & Single office & Double (SW) & $\mathrm{R}$ & 12.59 & 12.66 & 11.4 & 6.2 & 167.9 \\
\hline G.1 & Single office & Double (SW) & $\mathrm{R}$ & 12.09 & 12.05 & 11.9 & 6.4 & - \\
\hline G.2 & Single office & Single (SW) & NR & 12.18 & 12.2 & 11.8 & 6.4 & 48.4 \\
\hline G.3 & $\begin{array}{l}\text { Conference } \\
\text { room }\end{array}$ & Single (SW) & NR & 30.47 & 2.54 & 14.2 & 2.6 & 10.9 \\
\hline G.4 & Single office & Single (SW) & NR & 12.33 & 12.35 & 11.7 & 6.4 & 48 \\
\hline G.5 & Single office & Single (SW) & NR & 12.16 & 12.2 & 11.8 & 6.4 & 77.1 \\
\hline G.6 & Single office & Single (SW) & NR & 12.38 & 12.35 & 23.2 & 6.3 & 47.7 \\
\hline G.7 & Single office & Double (SW) & $\mathrm{R}$ & 18.18 & 18.18 & 15.8 & 4.3 & 118.4 \\
\hline G. 8 & Single office & Single (SW) & NR & 18.6 & 18.52 & 15.5 & 4.2 & 115.9 \\
\hline G.9 & Single office & Single (SW) & NR & 11.96 & 11.9 & 12 & 6.5 & 51.5 \\
\hline G.10 & Single office & Single (SW) & NR & 12.14 & 12.2 & 11.9 & 6.4 & 174.9 \\
\hline G.11 & Single office & Single (NW) & NR & 18.7 & 18.87 & 15.4 & 1.4 & - \\
\hline G.12 & Single office & Double (NW) & $\mathrm{R}$ & 27.01 & 27.78 & 15.5 & 2.8 & 21.2 \\
\hline G.13 & $\begin{array}{l}\text { Conference } \\
\text { room }\end{array}$ & Single (NE) & NR & 62.66 & 2.61 & 13.8 & 1.3 & 52.4 \\
\hline G.14 & Open plan office & Double (NE) & $\mathrm{R}$ & 36.6 & 4.98 & 12.4 & 15.7 & 63.2 \\
\hline G.15 & Computer lab & Single (NE) & NR & 44.72 & 2.13 & 14.5 & 33.1 & 29.1 \\
\hline G.16 & Open plan office & Double (NE) & $\mathrm{R}$ & 53.35 & 5.43 & 15.9 & 14.4 & 73.1 \\
\hline G.17 & Single office & Single (NE) & NR & 26.82 & 6.71 & 16.1 & 8.7 & 14.7 \\
\hline G.18 & Single office & Single (NE) & NR & 17.99 & 17.86 & 12 & 4.3 & 32.8 \\
\hline $\begin{array}{c}\text { GF } \\
\text { Corridor }\end{array}$ & Corridor & - & - & 83.66 & - & 6.8 & - & - \\
\hline F.1 & Lecture room & Double (SW) & $\mathrm{R}$ & 91.2 & 1.3 & 12.6 & - & 3 \\
\hline F.2 & Lecture room & Double $(\mathrm{SW})$ & $\mathrm{R}$ & 73.97 & 1.32 & 15.6 & - & 3.7 \\
\hline F.3 & Lecture room & Double (SW) & $\mathrm{R}$ & 89.03 & 1.27 & 12.9 & - & 3.1 \\
\hline F.4 & Lecture room & Double (SW) & $\mathrm{R}$ & 88.87 & 1.27 & 13 & - & 3.1 \\
\hline F.5 & $\mathrm{Lab}$ & Double (NW) & $\mathrm{R}$ & 85.89 & 2.15 & 10.9 & 1.8 & 3.2 \\
\hline F.6 & $\mathrm{Lab}$ & Double (NW) & $\mathrm{R}$ & 36.89 & 7.35 & 10.9 & 1.1 & - \\
\hline $\begin{array}{c}\text { FF } \\
\text { Corridor1 }\end{array}$ & Corridor & Double (NE) & $\mathrm{R}$ & 49.65 & - & 7.2 & - & - \\
\hline $\begin{array}{c}\text { FF } \\
\text { Corridor2 }\end{array}$ & Corridor & Double (NE) & $\mathrm{R}$ & 21.08 & - & 6.8 & - & - \\
\hline
\end{tabular}

Note: SW- South West, NW- North West, NE- North East, R-Retrofitted, NR-Non- Retrofitted

Please cite as: Zuhaib S., Hajdukiewicz M., \& Goggins J. (2019). 'Application of a staged automated calibration methodology to a partially-retrofitted university building energy model'. Journal of Building Engineering, 26, 100866. https://doi.org/10.1016/j.jobe.2019.100866 


\subsection{Sensitivity analysis using Morris method}

The developed initial BEM was first used for sensitivity analysis using the Morris method that determines which factors may be considered to have effects that are negligible, linear and additive, or non-linear and involved in interactions with other input parameters [40], [72]. It is the least computationally expensive and widely used in building energy analysis and characterises the inputs based on the concept of elementary effects that are the firstorder derivatives of the model [72]-[74]. The mean $(\mu)$ and standard deviation $(\sigma)$ of elementary effects are determined at various sample points. Prior to calibration, the sensitivity analysis was conducted using SimLab 4.0 [62]. The inputs were pre-processed, and outputs were post-processed in SimLab. The jEPlus [63] environment was used to run the batch simulations using the EnergyPlus engine (Figure 1(b)) coupled with SimLab.

The steps taken for sensitivity analysis using the Morris method [61], [75] included:

\section{i. Determination of objective and output variables}

In the case study energy model, the primary objective was focused on determining energy performance; therefore, the output variable of space heating demand $\left(\mathrm{kWh} \mathrm{m}^{-2} \mathrm{yr}^{-1}\right)$ was defined. The objectives can also be focused on IEQ (PMV/PPD, indoor temperature, $\mathrm{CO}_{2}$ levels etc.), but only one objective can be taken at a time.

\section{ii. Selection and definition of Probability Density Functions (PDFs)}

Each parameter and their typical values for PDFs were defined based on architectural, economic, technical possibilities or limitations of the case study building [73]. A list of values and ranges for the 51 parameters employed in the sensitivity analysis are given in Table 6. A large parameter set took into account the uncertainties due to age and partial-retrofit of the building that implied variations in construction and occupant preferences in different zones and, thus, difficult to generalise parameters for typical zones [58]. These parameters were assumed to have normal distribution due to large parameter ranges and uncertainty [76]. The initial values were derived from data collected through audits, documentation, standards and calculations based on available information as discussed in Section 4.1. The set of parameters that were generally considered for the calibration of a BEM included U-values, loads and set points [60], [61]. The mean and standard deviations of different parameters have been defined based on the literature from which the threshold values of parameters (minimum and maximum) were derived [37], [73], [77], [78]. The values of parameters in Table 6 were defined within SimLab based on their PDFs and for each parameter, several samples were pre-processed in the next step under the Morris method. 


\section{iii. Generation of simulation input parameters using random sampling (factorial sampling)}

Based on the PDF of each simulation parameter, random samples [40], [79] of simulation parameters were generated by Morris factorial sampling [72] in SimLab in this study. The procedure was repeated $r$ (random trajectories) times creating a set of $r(k+1)$ simulations, where $k$ is the number of simulation input parameters. In order to reasonably cover for all simulation parameters, a minimum value of $r=4$ is recommended in the literature. Therefore, if there are 51 simulation parameters, then the corresponding simulations to calculate the output will be $4(51+1)=208$.

\section{iv. Calculation of output variables}

The random samples obtained for each simulation parameter in the previous step were used as inputs for the simulation to calculate the output variable (total heating energy demand). The output variable was generated for 208 simulations for each sample of simulation input parameters and this was done using jEPlus along with the EnergyPlus engine. In the next step, the outputs were post-processed in SimLab to evaluate the sensitivity of each parameter based on elementary effects.

\section{v. Relative ranking of simulation parameters based on its impact on the output variables}

The main purpose of assessing the influence of each simulation parameter was to determine the effects which were i) negligible, ii) linear or additive, and iii) non-linear. The Morris method determines the elementary effect (EE) of a model $y=y\left(x_{1} \ldots x_{k}\right)$ with input (simulation) parameters $x_{i}$. The elementary effect for the $i^{\text {th }}$ input parameter in a point $x_{i}$ is

$E E_{i}\left(x_{1}, \ldots, x_{k}\right)=\frac{y\left(x_{1}, x_{2} \ldots x_{i-1}, x_{i}+\Delta, x_{i+1}, \ldots x_{k}\right)-y\left(x_{1}, \ldots x_{k}\right)}{\Delta_{i}}$

where, $\Delta_{\mathrm{t}}$ is the pre-defined step for input parameter $i$.

Several elementary effects $\mathrm{EE}_{i}$ of each design parameter were calculated based on the generated samples of each design parameter in step three, i.e. the chosen value of $r$. The model sensitivity to each simulation parameter was evaluated by the mean and the standard deviation of the elementary effects [72]. 


\begin{tabular}{|c|c|c|c|c|c|c|c|c|c|c|}
\hline Model component & Code & Parameter & Unit & $\begin{array}{c}\text { Source of initial } \\
\text { value }\end{array}$ & $\begin{array}{r}\begin{array}{r}\text { Initial model } \\
\text { value }\end{array} \\
\end{array}$ & Min & Max & $\mu^{\prime}(\operatorname{mean})$ & $\begin{array}{l}\sigma^{\prime} \text { (standard } \\
\text { deviation) }\end{array}$ & $\begin{array}{c}\text { Reference for }\left(\mu^{\prime}\right) \\
\text { and }\left(\sigma^{\prime}\right)\end{array}$ \\
\hline \multirow{4}{*}{$\begin{array}{l}\text { External wall } \\
\text { insulation }\end{array}$} & P1 & Conductivity & $\mathrm{W} \mathrm{m}^{-1} \mathrm{~K}^{-1}$ & \multirow{11}{*}{ Datasheets from audit } & 0.049 & 0.044 & 0.054 & 0.049 & 0.003 & \multirow{4}{*}{ [73] } \\
\hline & P2 & Thickness & $\mathrm{m}$ & & 0.1 & 0.09 & 0.11 & 0.1 & 0.01 & \\
\hline & P3 & Density & $\mathrm{kg} \mathrm{m}^{-3}$ & & 265 & 238.5 & 291.5 & 265 & 18.7 & \\
\hline & P4 & Specific heat & $\mathrm{J} \mathrm{kg}^{-1} \mathrm{~K}^{-1}$ & & 836.8 & 753.1 & 920.5 & 836.8 & 59.2 & \\
\hline \multirow{3}{*}{ Internal wall } & P5 & Conductivity & $\mathrm{W} \mathrm{m}^{-1} \mathrm{~K}^{-1}$ & & 0.72 & 0.65 & 0.79 & 0.72 & 0.05 & \multirow{3}{*}{ [73] } \\
\hline & P6 & Density & $\mathrm{kg} \mathrm{m}^{-3}$ & & 1920 & 1728 & 2112 & 1920 & 135.76 & \\
\hline & P7 & Specific heat & $\mathrm{J} \mathrm{kg}^{-1} \mathrm{~K}^{-1}$ & & 840 & 756 & 924 & 840 & 59.4 & \\
\hline \multirow{4}{*}{ Roof insulation } & P8 & Conductivity & $\mathrm{W} \mathrm{m}^{-1} \mathrm{~K}^{-1}$ & & 0.049 & 0.044 & 0.054 & 0.049 & 0.003 & \multirow{4}{*}{ [73] } \\
\hline & P9 & Thickness & $\mathrm{m}$ & & 0.088 & 0.079 & 0.097 & 0.088 & 0.01 & \\
\hline & P10 & Density & $\mathrm{kg} \mathrm{m}^{-3}$ & & 265 & 238.5 & 291.5 & 265 & 18.74 & \\
\hline & P11 & Specific heat & $\mathrm{J} \mathrm{kg}^{-1} \mathrm{~K}^{-1}$ & & 836.8 & 753.1 & 920.5 & 836.8 & 59.17 & \\
\hline Surface temperature & P12 & $\begin{array}{l}\text { Surface temperature (outside building } \\
\text { surface in contact with ground) }\end{array}$ & ${ }^{\circ} \mathrm{C}$ & $\begin{array}{l}\text { Calculated based on } \\
\text { average zone } \\
\text { temperatures }\end{array}$ & 9 & 8.1 & 9.9 & 9 & 0.64 & Estimated [80] \\
\hline \multirow{7}{*}{ Envelope } & P13 & Air infiltration (Retrofitted zones) & $\mathrm{ACH}$ & Measured from blower & 2.3 & 0.92 & 3.68 & 2.3 & 0.98 & \\
\hline & P14 & Air infiltration (Non-retrofitted zones) & $\mathrm{ACH}$ & door test & 3.02 & 1.96 & 4.08 & 3.02 & 0.75 & [73] \\
\hline & P15 & Ventilation rate- Single offices & $\mathrm{ACH}$ & \multirow{5}{*}{$\begin{array}{c}\text { From previous IEQ } \\
\text { study [58] }\end{array}$} & 2.9 & 2.03 & 3.77 & 2.9 & 0.62 & \multirow{3}{*}{ [81] } \\
\hline & P16 & Ventilation rate- Post grad room & $\mathrm{ACH}$ & & 1.6 & 1.12 & 2.08 & 1.6 & 0.34 & \\
\hline & P17 & Ventilation rate- Conference room & $\mathrm{ACH}$ & & 2.1 & 1.47 & 2.73 & 2.1 & 0.45 & \\
\hline & P18 & Ventilation rate- Lab & $\mathrm{ACH}$ & & 2 & 1.4 & 2.6 & 2 & 0.42 & \multirow{6}{*}{ [77] } \\
\hline & P19 & Ventilation rate- Lecture room & $\mathrm{ACH}$ & & 4.2 & 2.94 & 5.46 & 4.2 & 0.89 & \\
\hline \multirow{6}{*}{ Windows } & $\mathrm{P} 20$ & Solar transmittance (SHGC)-double glazing & - & \multirow{7}{*}{ Datasheets from audit } & 0.761 & 0.685 & 0.837 & 0.761 & 0.05 & \\
\hline & P21 & Solar transmittance (SHGC)-single glaing & - & & 0.837 & 0.753 & 0.921 & 0.837 & 0.06 & \\
\hline & P22 & Visible transmittance-double glazing & - & & 0.807 & 0.726 & 0.888 & 0.807 & 0.06 & \\
\hline & P23 & Visible transmittance-single glaing & - & & 0.899 & 0.809 & 0.989 & 0.899 & 0.06 & \\
\hline & $\mathrm{P} 24$ & Double glazing U-value & $\mathrm{W} \mathrm{m}^{-2} \mathrm{~K}^{-1}$ & & 2.72 & 2.45 & 2.99 & 2.72 & 0.19 & \multirow{2}{*}{ [73] } \\
\hline & $\mathrm{P} 25$ & Single glazing U-value & $\mathrm{W} \mathrm{m}^{-2} \mathrm{~K}^{-1}$ & & 5.78 & 5.2 & 6.36 & 5.78 & 0.41 & \\
\hline Shading & P26 & Vertical blinds- conductivity & $\mathrm{W} \mathrm{m}^{-1} \mathrm{~K}^{-1}$ & & 0.2 & 0.18 & 0.22 & 0.2 & 0.01 & [77] \\
\hline \multirow{13}{*}{ Internal Loads } & P27 & Equipment loads- Single office & $\mathrm{W} \mathrm{m}^{-2}$ & \multirow{10}{*}{$\begin{array}{l}\text { Measured and } \\
\text { calculated on-site }\end{array}$} & 77.6 & 65.96 & 89.24 & 77.6 & 8.23 & \multirow{13}{*}{ Estimated } \\
\hline & P28 & Equipment loads- Post grad room & $\mathrm{W} \mathrm{m}^{-2}$ & & 56.7 & 48.2 & 65.21 & 56.7 & 6.01 & \\
\hline & P29 & Equipment loads- Conference & $\mathrm{W} \mathrm{m}^{-2}$ & & 33.5 & 28.48 & 38.53 & 33.5 & 3.55 & \\
\hline & $\mathrm{P} 30$ & Equipment loads- Lab & $\mathrm{W} \mathrm{m}^{-2}$ & & 3.05 & 2.59 & 3.51 & 3.05 & 0.32 & \\
\hline & $\mathrm{P} 31$ & Equipment loads- Lecture room & $\mathrm{W} \mathrm{m}^{-2}$ & & 3.22 & 2.74 & 3.7 & 3.22 & 0.34 & \\
\hline & $\mathrm{P} 32$ & Lighting Power Density - Single office & $\mathrm{W} \mathrm{m}^{-2}$ & & 12.86 & 10.93 & 14.79 & 12.86 & 1.36 & \\
\hline & P33 & Lighting Power Density - Post grad room & $\mathrm{W} \mathrm{m}^{-2}$ & & 14.81 & 12.59 & 17.03 & 14.81 & 1.57 & \\
\hline & P34 & Lighting Power Density - Conference & $\mathrm{W} \mathrm{m}^{-2}$ & & 14 & 11.9 & 16.1 & 14 & 1.48 & \\
\hline & P35 & Lighting Power Density - Lab & $\mathrm{W} \mathrm{m}^{-2}$ & & 11.3 & 9.61 & 13 & 11.3 & 1.2 & \\
\hline & P36 & Lighting Power Density - Lecture room & $\mathrm{W} \mathrm{m}^{-2}$ & & 13.5 & 11.48 & 15.53 & 13.5 & 1.43 & \\
\hline & P37 & Occupant density- Single office & person $\mathrm{m}^{-2}$ & \multirow{3}{*}{$\begin{array}{c}\text { Calculated from audit } \\
\text { and room booking } \\
\text { data }\end{array}$} & 0.07 & 0.05 & 0.09 & 0.07 & 0.01 & \\
\hline & P38 & Occupant density- Post grad room & person $\mathrm{m}^{-2}$ & & 0.19 & 0.13 & 0.25 & 0.19 & 0.04 & \\
\hline & P39 & Occupant density- Conference & person $\mathrm{m}^{-2}$ & & 0.39 & 0.27 & 0.51 & 0.39 & 0.08 & \\
\hline
\end{tabular}

Please cite as: Zuhaib S., Hajdukiewicz M., \& Goggins J. (2019). 'Application of a staged automated calibration methodology to a partially-retrofitted university building energy model'. Journal of Building Engineering, 26, 100866. https://doi.org/10.1016/j.jobe.2019.100866 


\begin{tabular}{|c|c|c|c|c|c|c|c|c|c|c|}
\hline & P40 & Occupant density- Lab & person $\mathrm{m}^{-2}$ & & 0.3 & 0.21 & 0.39 & 0.3 & 0.06 & \\
\hline & P41 & Occupant density- Lecture room & person $\mathrm{m}^{-2}$ & & 0.77 & 0.54 & 1 & 0.77 & 0.16 & \\
\hline \multirow{7}{*}{ Control } & P42 & Indoor Heating setpoint- Single office & ${ }^{\circ} \mathrm{C}$ & \multirow{6}{*}{ EN15251[82] } & 20 & 18 & 22 & 20 & 1.41 & \multirow{6}{*}{ Estimated } \\
\hline & $\mathrm{P} 43$ & Indoor Heating setpoint- Post grad room & ${ }^{\circ} \mathrm{C}$ & & 20 & 18 & 22 & 20 & 1.41 & \\
\hline & P44 & Indoor Heating setpoint- Conference room & ${ }^{\circ} \mathrm{C}$ & & 20 & 18 & 22 & 20 & 1.41 & \\
\hline & P45 & Indoor Heating setpoint- Lab & ${ }^{\circ} \mathrm{C}$ & & 20 & 18 & 22 & 20 & 1.41 & \\
\hline & P46 & Indoor Heating setpoint- Lecture room & ${ }^{\circ} \mathrm{C}$ & & 20 & 18 & 22 & 20 & 1.41 & \\
\hline & P47 & Indoor Heating setpoint- Corridor & ${ }^{\circ} \mathrm{C}$ & & 18 & 16.2 & 19.8 & 18 & 1.27 & \\
\hline & P48 & Pump efficiency & - & Label data & 0.75 & 0.64 & 0.86 & 0.75 & 0.1 & [83] \\
\hline \multirow{3}{*}{ Internal gains } & P49 & Lighting heat gain radiant fraction & - & \multirow{3}{*}{ ASHRAE Handbook } & 0.1 & 0.09 & 0.12 & 0.1 & 0.01 & \multirow{3}{*}{ [77] } \\
\hline & P50 & Equipment heat gain radiant fraction & - & & 0.1 & 0.09 & 0.12 & 0.1 & 0.01 & \\
\hline & P51 & Occupant heat gain radiant fraction & - & & 0.3 & 0.26 & 0.35 & 0.3 & 0.03 & \\
\hline
\end{tabular}

Please cite as: Zuhaib S., Hajdukiewicz M., \& Goggins J. (2019). 'Application of a staged automated calibration methodology to a partially-retrofitted university building energy model'. Journal of Building Engineering, 26, 100866. https://doi.org/10.1016/j.jobe.2019.100866 
The method of elementary effects was used for this purpose, where each parameter was evaluated using the mean $(\mu)$ and standard deviation $(\sigma)[84]$ :

$\mu=\sum_{i=1}^{r} \frac{\left|\mathrm{EE}_{i}\right|}{r}$

$\sigma=\sqrt{\sum_{i=1}^{r} \frac{\left|E E_{i}-\mu^{2}\right|}{r}}$

where $\mu$ is the mean value of the absolute values of outputs if the simulation parameter is important and $\sigma$ is the standard deviation of the outputs which is a measure of all interactions with other factors. The results of the sensitivity analysis and ranking of parameters are discussed in the next section.

\section{Results and discussion}

\subsection{Sensitivity analysis results}

The list of 51 parameters presented in Section 4.3 were analysed using the Morris method for screening. A resulting elementary effects plot between $\mu$ and $\sigma$, determined through equations (6) and (7) (from Section 4.3), is illustrated in Figure 5, which shows parameters in the ranges of $\sigma / \mu \leq 0.1$ (linear), $0.1<\sigma / \mu \leq 0.5$ (almost monotonic), $0.5<\sigma / \mu \leq 1$ (monotonic), and for others that have $\sigma / \mu>1$ are non-monotonic and non-linear [35].

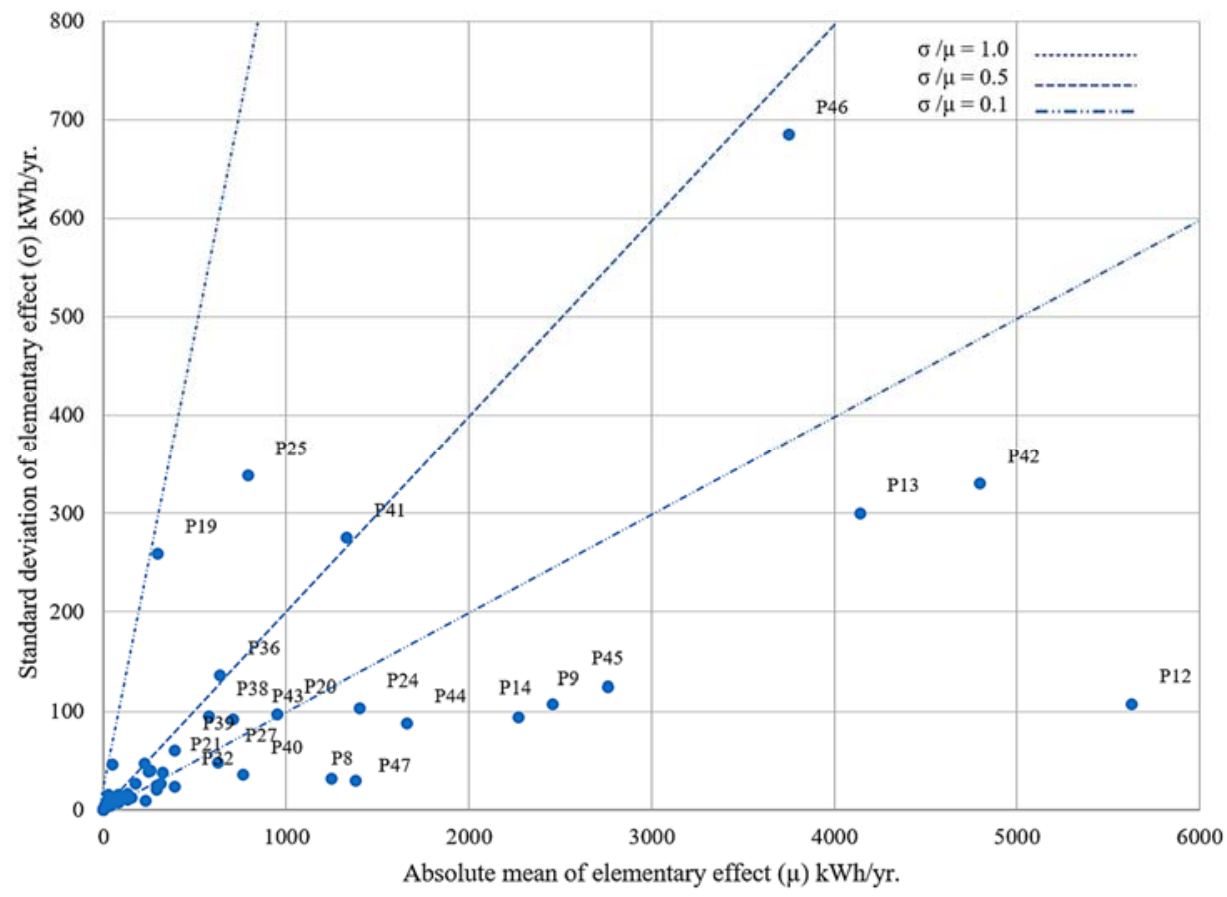

Figure 5 Sensitivity analysis results 
The result of the sensitivity analysis was a list of important simulation parameters and a ranking of the simulation parameters by the strength of their impact on the output $\mu$ (absolute mean of elementary effect), as shown in Table 7. Based on input categorisation in Table 7, zone set-points impact ( $\mu$ ) (single offices, lecture rooms, laboratories, conference rooms, post-graduate researcher rooms and corridor) and infiltration rates impact ( $\mu$ ) (retrofitted and non-retrofitted) contributed to the highest uncertainty in the model results. Since outside building surface temperature in touch with the ground has lower fluctuations annually, it has lower uncertainty compared to the combined set points and combined infiltration rates of all the zones [76]. However, due to the absence of floor insulation in the BEM, the large impact is visible on $\mu$ owing to large floor surface area in contact with the ground. Among others, double glazing U-value and roof insulation thickness were also influential on the output. It is recommended in literature to limit the calibration parameters to 25 or lower in case of a higher number of optimisation parameters [44]. Therefore, the top 25 parameters were chosen for calibration in the next section.

Table 7 Top 25 ranking parameters after sensitivity analysis

\begin{tabular}{|c|c|c|c|}
\hline Parameters & & Rank & 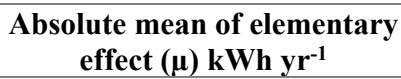 \\
\hline P12 & $\begin{array}{l}\text { Surface temperature (outside building surface in } \\
\text { contact with ground) }\end{array}$ & 1 & 5630 \\
\hline $\mathrm{P} 42$ & Indoor Heating Setpoint-Single office & 2 & 4800 \\
\hline $\mathrm{P} 13$ & Air infiltration (Retrofitted zones) & 3 & 4140 \\
\hline P46 & Indoor Heating Setpoint-Lecture room & 4 & 3750 \\
\hline P45 & Indoor Heating Setpoint- Lab & 5 & 2760 \\
\hline P9 & Roof insulation thickness & 6 & 2460 \\
\hline P14 & Air infiltration (non-retrofitted zones) & 7 & 2270 \\
\hline P44 & Indoor Heating Setpoint- Conference & 8 & 1660 \\
\hline $\mathrm{P} 24$ & Double glazing U-value & 9 & 1400 \\
\hline P47 & Indoor Heating Setpoint- Corridor & 10 & 1380 \\
\hline P41 & Occupant density-Lecture room & 11 & 1330 \\
\hline P8 & Roof insulation conductivity & 12 & 1250 \\
\hline P20 & Solar transmittance (SHGC)-double glazing & 13 & 948 \\
\hline $\mathrm{P} 25$ & Single glazing U-value & 14 & 789 \\
\hline P40 & Occupant density- Lab & 15 & 764 \\
\hline P43 & Indoor Heating Setpoint- Post grad room & 16 & 708 \\
\hline P36 & Lighting Power density- Lecture room & 17 & 639 \\
\hline $\mathrm{P} 27$ & Equipment loads- Single office & 18 & 624 \\
\hline P38 & Occupant density- Post-grad room & 19 & 576 \\
\hline P39 & Occupant density- Conference & 20 & 391 \\
\hline P32 & Lighting Power density- Single office & 21 & 386 \\
\hline P21 & Solar transmittance (SHGC)-single glazing & 22 & 323 \\
\hline P33 & Lighting Power density- Post grad room & 23 & 312 \\
\hline P19 & Ventilation rate- Lecture room & 24 & 295 \\
\hline P28 & Equipment loads- Lecture room & 25 & 291 \\
\hline
\end{tabular}

\subsection{Staged automated calibration}

The selected calibration parameters include thermo-physical properties (U-values, density, thickness etc.) and occupant behaviour related (ventilation, setpoints, occupant density, lighting power density, equipment loads etc.) parameters. The former are generally constant over a period, but the latter fluctuate with the changes in behaviour 
and, therefore, are very crucial in achieving accurate calibration. To minimise the uncertainty in inputs of occupant behaviour the schedules were prepared by generalising the behaviour of a week over a month and by clustering them based on running semester schedules. This allowed the complexity to be reduced while achieving better accuracy in modelling and calibration. The outdoor meteorological conditions impact greatly on the variation in energy demand and IEQ parameters. However, in this study local weather station data has been used that was not required to be calibrated. Air-infiltration values for the retrofitted and non-retrofitted zones were assumed to be constant during the occupied hours and, thus, calibrated in this section. Initial heating setpoints during calibration were based on defaults from EN15251 [85] initially and later the measured setpoints were used.

As outlined in the methodology section, the calibration was divided into two-stages. The first-stage calibration involved the use of the initial BEM created with as-built components and data as highlighted in Section 3. The measured monthly utility data of heating and electrical energy consumption was used as reference data for the first-stage calibration. During the second-stage calibration, both the monthly utility data and an extensive set of measured indoor thermal environment data, collected through long-term monitoring of indoor air temperature using data-loggers in the previous field study [58], were used as reference data. Results were validated [86] after calibration against the acceptance criteria in ASHRAE Guideline 14 [45]. The following sections elaborate on the results of automated calibration obtained from the two stages.

\subsubsection{First-stage calibration}

The top 25 parameters identified in Section 5.1 were used for the first-stage calibration process. The initial building energy model used for the sensitivity analysis was employed in the first-stage calibration, during which 26 parameters were maintained at their initial value due to the relatively low impact of varying them on simulation results. The resolution of input data employed in the BEM for model calibration during this stage corresponds to a near accurate representation of the real building conditions, as the information used represents Level 1-4 [55]. The input parameters P42, P43, P44, P45, P46 given in Table 8 were based on the standard EN15251 [82] during this stage of calibration, as measured set-points were not used. Table 8 gives the minimum, maximum and step values used for the automated calibration (tuning of parameters). A two-objective optimisation was conducted on the model corresponding to a minimisation of $\mathrm{Cv}(\mathrm{RMSE})_{\text {Monthly }}$ and $\mathrm{NMBE}_{\text {Monthly }}$ values for the model based on measured and simulated data of the monthly heating and electrical consumption. During the first-stage calibration, the convergence was achieved after 140 generations, as no more optimal solutions were found and the optimisation 
was terminated. The pareto frontier obtained after convergence is given in Figure 6. The 'knee' point [87] of the pareto front was selected as the most optimal solution for further stage calibration.

Table 8 Selected top 25 input parameters for first-stage calibration

\begin{tabular}{clrrr}
\hline Parameters & & Min & Step & Max \\
\hline P12 & Ground temperature- outside building surface & 8.1 & 0.450 & 9.9 \\
\hline P42 & Indoor Heating Setpoint-Single office & 18 & 1.000 & 22 \\
\hline P13 & Air infiltration (Retrofitted zones) & 0.92 & 0.690 & 3.68 \\
\hline P46 & Indoor Heating Setpoint-Lecture room & 18 & 1.000 & 22 \\
\hline P45 & Indoor Heating Setpoint- Lab & 18 & 1.000 & 22 \\
\hline P9 & Roof insulation thickness & 0.079 & 0.005 & 0.097 \\
\hline P14 & Air infiltration (non-retrofitted zones) & 1.96 & 0.530 & 4.08 \\
\hline P44 & Indoor Heating Setpoint- Conference & 18 & 1.000 & 22 \\
\hline P24 & Double glazing U-value & 2.448 & 0.136 & 2.992 \\
\hline P47 & Indoor Heating Setpoint- Corridor & 16 & 1.000 & 20 \\
\hline P41 & Occupant density-Lecture room & 0.54 & 0.115 & 1 \\
\hline P8 & Roof insulation conductivity & 0.044 & 0.003 & 0.054 \\
\hline P20 & Solar transmittance (SHGC)-double glazing & 0.685 & 0.038 & 0.837 \\
\hline P25 & Single glazing U-value & 5.2 & 0.290 & 6.36 \\
\hline P40 & Occupant density- Lab & 0.21 & 0.045 & 0.39 \\
\hline P43 & Indoor Heating Setpoint- Post grad room & 18 & 1.000 & 22 \\
\hline P36 & Lighting Power density- Lecture room & 11.475 & 1.013 & 15.525 \\
\hline P27 & Equipment loads- Single office & 65.96 & 5.820 & 89.24 \\
\hline P38 & Occupant density- Post-grad room & 0.13 & 0.030 & 0.25 \\
\hline P39 & Occupant density- Conference & 0.27 & 0.060 & 0.51 \\
\hline P32 & Lighting Power density- Single office & 10.93 & 0.965 & 14.79 \\
\hline P21 & Solar transmittance (SHGC)-single glazing & 0.753 & 0.042 & 0.921 \\
\hline P33 & Lighting Power density- Post grad room & 12.59 & 1.110 & 17.03 \\
\hline P19 & Ventilation rate- Lecture room & 2.94 & 0.630 & 5.46 \\
\hline P28 & Equipment loads- Lecture room & 4.253 & 65.21 \\
\hline & & & \\
\hline
\end{tabular}

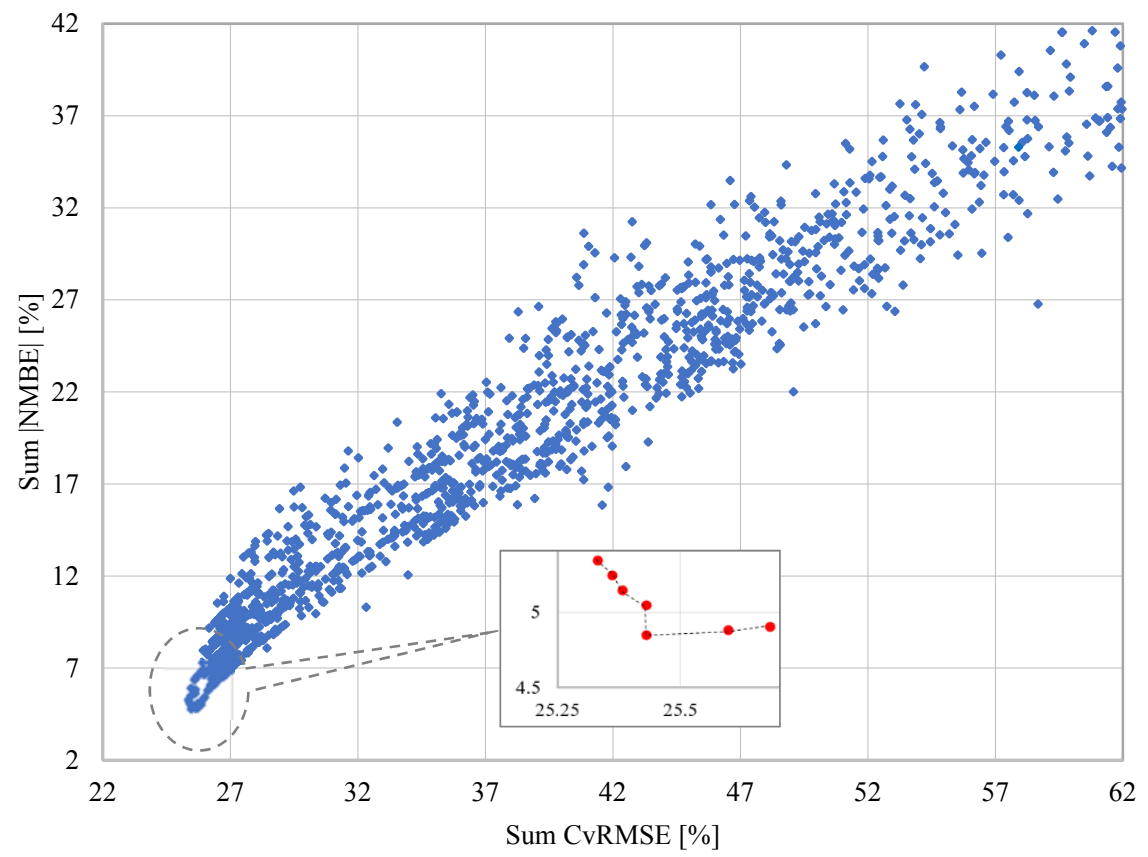

Figure 6 Pareto frontier after first-stage calibration 
The first-stage calibration results are shown in Table 9 validated against the indices of $\operatorname{Cv}(\mathrm{RMSE})_{\text {Monthly }}$ and

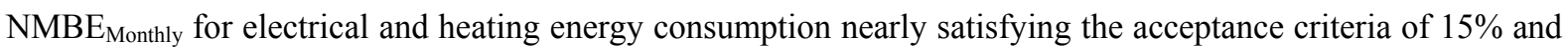
$5 \%$, respectively (Table 1). There were 25 zones in the simulation, but due to space constraints for data presentation only representative zones (G.0, G.1, G.3, G.10, G.12, F.1, F.4, F.6) are used for discussion of results.

Table 9 First-stage calibration results

\begin{tabular}{|c|c|c|}
\hline & Cv(RMSE)Monthly $[\%]$ & NMBE $_{\text {Monthly }}[\%]$ \\
\hline $\begin{array}{l}\text { Total Electricity } \\
\text { consumption }\end{array}$ & 15.5 & 0.1 \\
\hline $\begin{array}{l}\text { Heating energy } \\
\text { consumption }\end{array}$ & 9.8 & 4.7 \\
\hline Indoor air temperature & Cv(RMSE)Hourly [\%] & 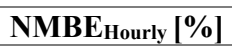 \\
\hline Single Office (G.0) & 25.5 & 16.2 \\
\hline Single Office (G.1) & 26.7 & 8.9 \\
\hline Conference Room (G.3) & 28.4 & 14.7 \\
\hline Single Office (G.10) & 23.4 & 7.7 \\
\hline Single Office (G.12) & 27.3 & 12.7 \\
\hline Open plan office (G.14) & 27.0 & 12.8 \\
\hline Lecture room (F.1) & 24.3 & 15.4 \\
\hline Lecture room (F.4) & 29.8 & 15.7 \\
\hline Lab (F.6) & 28.6 & 14.8 \\
\hline
\end{tabular}

The model results obtained during the first-stage calibration were also separately checked for the hourly indices of indoor air temperature to validate the model and it was observed that $\mathrm{Cv}(\mathrm{RMSE})_{\text {Hourly }}$ were lower than $30 \%$ for all the representative zones, but failed the criteria for $\mathrm{NMBE}_{\mathrm{Hourly}}$ as most of the values exceeded the $10 \%$ criteria. Therefore, second-stage calibration was required to satisfy the acceptance criteria using high resolution reference data and improve the accuracy of the model. These results were associated with the period of June 2016 - May 2017.

\subsubsection{Second-stage calibration}

The first-stage calibration model was used in the second-stage calibration. In other words, all the input parameters were set as those obtained at the end of the first stage calibration. The same steps defined in Table 8 were used for each parameter, except the indoor heating setpoint ranges were based on measured indoor temperature data in this stage. During this stage, detailed indoor monitoring temperature was available; therefore, it was used in preparation of setpoint schedules. The second-stage calibration began by defining the objectives of minimising $\mathrm{Cv}$ (RMSE) and NMBE for hourly indoor temperature data and setting the constraint boundaries for monthly heating and electrical energy consumption within the acceptance criteria defined in Section 2.3. For this stage, the hourly indoor air temperature was obtained by averaging measured 10-minute interval data for each hour for the duration of June 2016 to May 2017 due to simulation time-step used. The Pareto frontier was obtained after 
convergence for the optimisation objectives after 140 generations as presented in Figure 7 . The non-dominated best solutions are represented by red dots plotted between the sum of $\mathrm{Cv}(\mathrm{RMSE})$ and the sum of NMBE for all the zones. The 'knee' point was selected as the best solution for this stage.

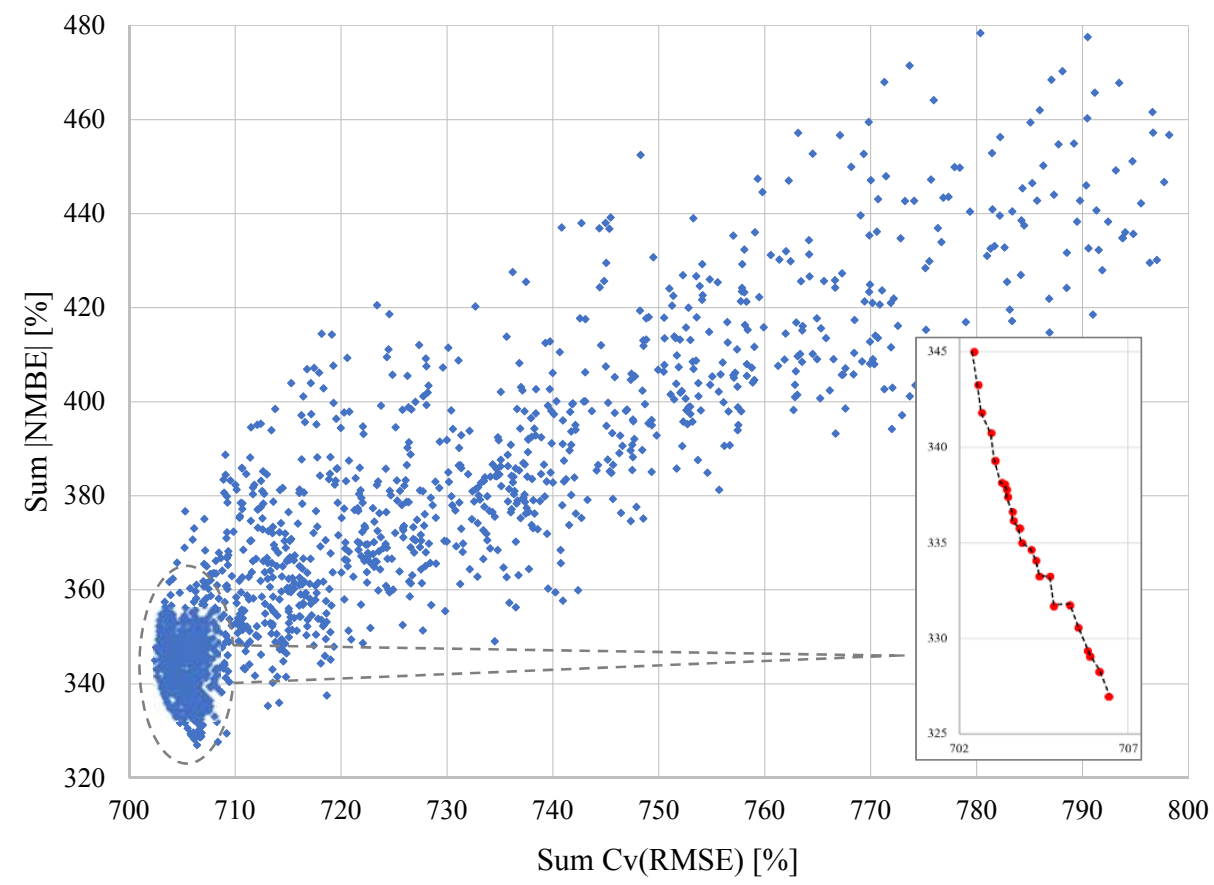

Figure 7 Pareto frontier for the second-stage calibration

Table 10 presents the results of monthly and hourly calibration results where both were validated against the

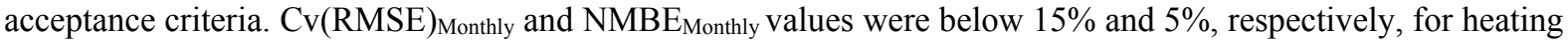
and electrical energy consumption. Although $\mathrm{Cv}(\mathrm{RMSE})_{\text {Hourly }}$ was below $30 \%$, high $\mathrm{NMBE}_{\text {Hourly values of indoor }}$ air temperature, except for few zones, indicated the presence of uncertainty in parameters and its impact on the output.

Table 10 Second-stage calibration results

\begin{tabular}{|c|c|c|}
\hline & $\operatorname{Cv}($ RMSE) Monthly $[\%]$ & NMBE $_{\text {Monthly }}[\%]$ \\
\hline $\begin{array}{c}\text { Total Electricity } \\
\text { consumption }\end{array}$ & 14.4 & 2.5 \\
\hline $\begin{array}{l}\text { Heating energy } \\
\text { consumption }\end{array}$ & 9.0 & 4.6 \\
\hline Indoor air temperature & Cv(RMSE)Hourly [\%] & NMBEHourly [\%] \\
\hline Single Office (G.0) & 19.2 & 8.3 \\
\hline Single Office (G.1) & 23.5 & 3.6 \\
\hline Conference Room (G.3) & 25.3 & 10.0 \\
\hline Single Office (G.10) & 22.0 & 2.9 \\
\hline Single Office (G.12) & 25.2 & 7.3 \\
\hline Open plan office (G.14) & 25.5 & 9.8 \\
\hline Lecture room (F.1) & 17.0 & 6.7 \\
\hline Lecture room (F.4) & 25.6 & 9.1 \\
\hline
\end{tabular}


Results analysis indicated that there was an improvement in the criteria for hourly indoor air temperature compared to the first-stage, where set points were taken based on EN15251 [85]. However, during the secondstage calibration, the set points were automatically tuned during optimisation to best represent the actual temperature data. An improvement in the calibration criteria of $\mathrm{Cv}(\mathrm{RMSE})$ for heating and electrical energy consumption was observed in Table 10 compared to first-stage results. Similar accuracies were also obtained in the other zones of the building for indoor air temperature data. However, high Cv(RMSE) and NMBE values depicted the presence of uncertainties in modelling the partially-retrofitted building to match the actual operational conditions. A comparison of monthly heating and electrical energy consumption for the measured data and simulation results from the two stages of calibration is shown in Figure 8 and Figure 9 corresponding to the duration of 2016-17. The monthly energy consumption results do not indicate major improvement, rather slight increase due to adjustment of indoor air temperature setpoint parameter values against reference datasets.

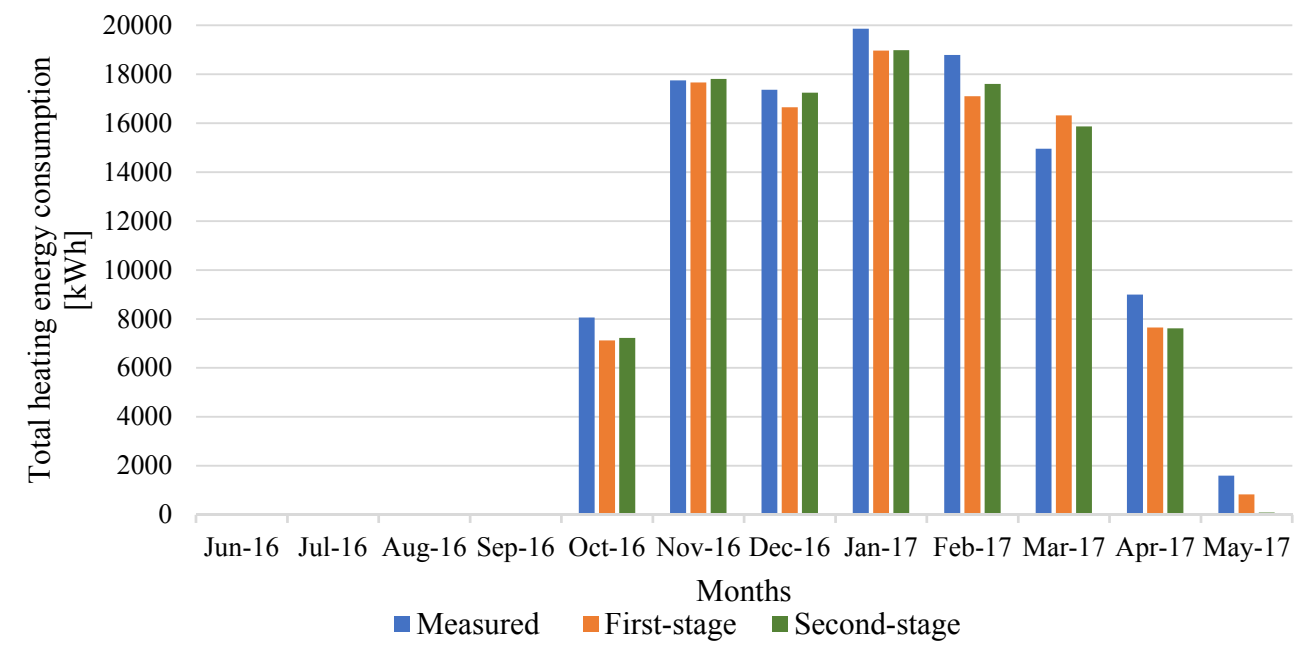

Figure 8 Monthly heating energy consumption comparison 


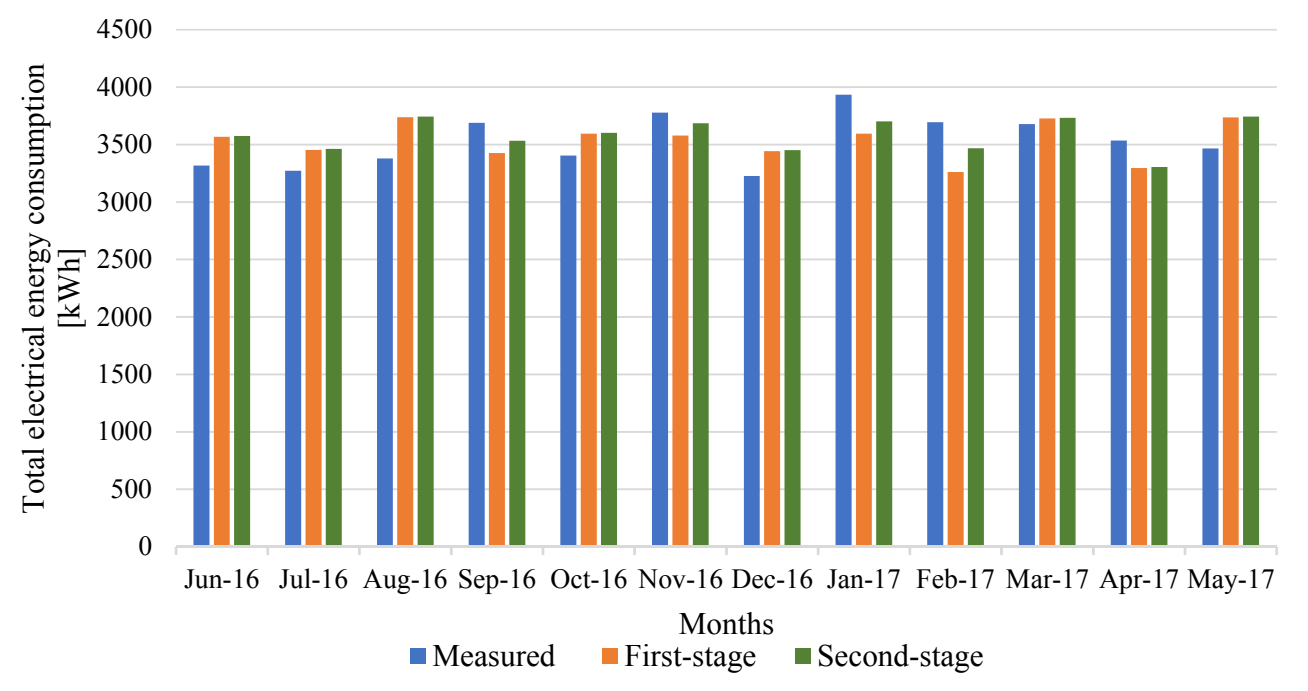

Figure 9 Monthly electrical energy comparison

The final set of 51 ( 25 calibrated plus 26 uncalibrated) parameter values after second-stage calibration are given in Table 11 representing the BEM and the near real conditions of the building for the simulation period after the automated calibration was conducted. The results of second-stage calibration highlighted that P13 attained a lower value compared to P14 depicting that retrofitted zones had lower infiltration rates than non-retrofitted zones. This was also confirmed by the field study where the blower door tests determined similar infiltration rates [58]. Measured room temperatures datasets during second-stage calibration converged the infiltration rate values to match the existing scenario of retrofitted and non-retrofitted rooms.

Table 11 Final set of model parameter values obtained after the model calibration

\begin{tabular}{|c|c|c|c|c|c|}
\hline Parameter & Unit & Value & Parameter & Unit & Value \\
\hline P1 & $\mathrm{W} \mathrm{m}^{-1} \mathrm{~K}^{-1}$ & 0.049 & $\mathbf{P 2 7}$ & $\mathrm{W} \mathrm{m}^{-2}$ & 95.93 \\
\hline P2 & $\mathrm{m}$ & 0.1 & P28 & $\mathrm{W} \mathrm{m}^{-2}$ & 65.21 \\
\hline P3 & $\mathrm{kg} \mathrm{m}^{-3}$ & 265 & P29 & $\mathrm{W} \mathrm{m}^{-2}$ & 33.5 \\
\hline P4 & $\mathrm{J} \mathrm{kg}^{-1} \mathrm{~K}^{-1}$ & 836.8 & P30 & $\mathrm{W} \mathrm{m}^{-2}$ & 3.05 \\
\hline P5 & $\mathrm{W} \mathrm{m} \mathrm{m}^{-1} \mathrm{~K}^{-1}$ & 0.72 & P31 & $\mathrm{W} \mathrm{m}^{-2}$ & 3.22 \\
\hline P6 & $\mathrm{kg} \mathrm{m}^{-3}$ & 1920 & P32 & $\mathrm{W} \mathrm{m}^{-2}$ & 14.79 \\
\hline P7 & $\mathrm{J} \mathrm{kg}^{-1} \mathrm{~K}^{-1}$ & 840 & P33 & $\mathrm{W} \mathrm{m}^{-2}$ & 17.1 \\
\hline P8 & $\mathrm{W} \mathrm{m} \mathrm{m}^{-1} \mathrm{~K}^{-1}$ & 0.046 & P34 & $\mathrm{W} \mathrm{m}^{-2}$ & 14 \\
\hline P9 & $\mathrm{m}$ & 0.087 & P35 & $\mathrm{W} \mathrm{m}^{-2}$ & 11.3 \\
\hline P10 & $\mathrm{kg} \mathrm{m}^{-3}$ & 265 & P36 & $\mathrm{W} \mathrm{m}^{-2}$ & 12.47 \\
\hline P11 & $\mathrm{J} \mathrm{kg}^{-1} \mathrm{~K}^{-1}$ & 836.8 & P37 & person $\mathrm{m}^{-2}$ & 0.07 \\
\hline P12 & ${ }^{\circ} \mathrm{C}$ & 8.91 & P38 & person $\mathrm{m}^{-2}$ & 0.17 \\
\hline P13 & $\mathrm{ACH}$ & 1.47 & P39 & person $\mathrm{m}^{-2}$ & 0.31 \\
\hline P14 & $\mathrm{ACH}$ & 2.63 & P40 & person $\mathrm{m}^{-2}$ & 0.24 \\
\hline P15 & $\mathrm{ACH}$ & 2.9 & P41 & person $\mathrm{m}^{-2}$ & 0.62 \\
\hline P16 & $\mathrm{ACH}$ & 1.6 & P42 & ${ }^{\circ} \mathrm{C}$ & 23 \\
\hline P17 & $\mathrm{ACH}$ & 2.1 & $\mathbf{P 4 3}$ & ${ }^{\circ} \mathrm{C}$ & 23 \\
\hline P18 & $\mathrm{ACH}$ & 2 & P44 & ${ }^{\circ} \mathrm{C}$ & 21 \\
\hline P19 & $\mathrm{ACH}$ & 3.38 & P45 & ${ }^{\circ} \mathrm{C}$ & 22 \\
\hline P20 & - & 0.754 & P46 & ${ }^{\circ} \mathrm{C}$ & 24 \\
\hline
\end{tabular}




\begin{tabular}{llllll}
\hline P21 & - & 0.828 & P47 & ${ }^{\circ} \mathrm{C}$ & 21 \\
\hline P22 & - & 0.807 & P48 & - & 0.75 \\
\hline P23 & - & 0.899 & P49 & - & 0.1 \\
\hline P24 & $\mathrm{W} \mathrm{m}^{-2} \mathrm{~K}^{-1}$ & 2.57 & $\mathbf{P 5 0}$ & - & 0.1 \\
\hline P25 & $\mathrm{W} \mathrm{m}^{-2} \mathrm{~K}^{-1}$ & 5.46 & $\mathbf{P 5 1}$ & - & 0.3 \\
\hline P26 & $\mathrm{W} \mathrm{m}^{-2} \mathrm{~K}^{-1}$ & 0.2 & & &
\end{tabular}

Comparisons of averaged daily indoor air temperature data between the measured and simulated data from the first and second-stage calibration results for representative zones are shown in Figure 10 (a-h). The simulated individual zone temporal annual temperature profiles match the trends and satisfied the required calibration criteria. However, these figures highlight the under-estimation by the model of indoor air temperature values due to uncertainties in the model inputs that may correspond to inaccuracies in physical properties of the building, rates of infiltration or ventilation, schedules and manual operation of thermostats (set points/setback), among others. The calibrated model shows under prediction of daily average temperatures during the summer (JuneAugust), winter (Dec-Feb), spring (Mar-May) and autumn (Sep-Nov) season. However, from mid-October to early-May the model prediction is better as the heating is operational and temperature fluctuations match the setpoint settings. Apart from this duration the building is naturally ventilated, therefore, the model predictions vary with greater deviations for indoor air temperature showing inability of the model to apply ventilation rate accurately. To identify the seasonal accuracy of the model, root mean square deviation (RMSD) between daily averaged measured and simulated II data were calculated for the single office G.0. Better accuracy was observed in the model results for winter $(\mathrm{RMSD}=2.23)$ and autumn $(\mathrm{RMSD}=2.28)$, followed by summer $(\mathrm{RMSD}=2.58)$ and spring $(\mathrm{RMSD}=2.86)$. 


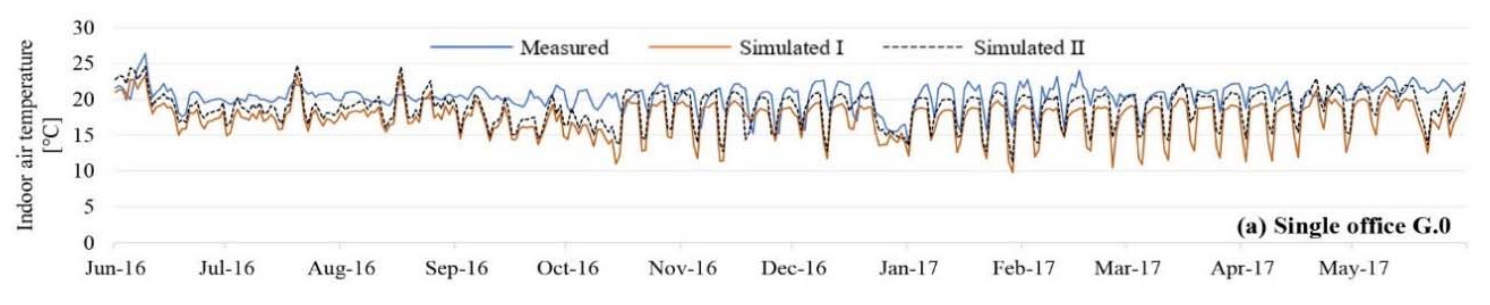

I.s.

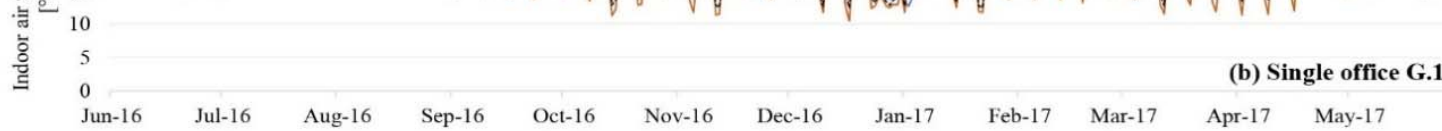

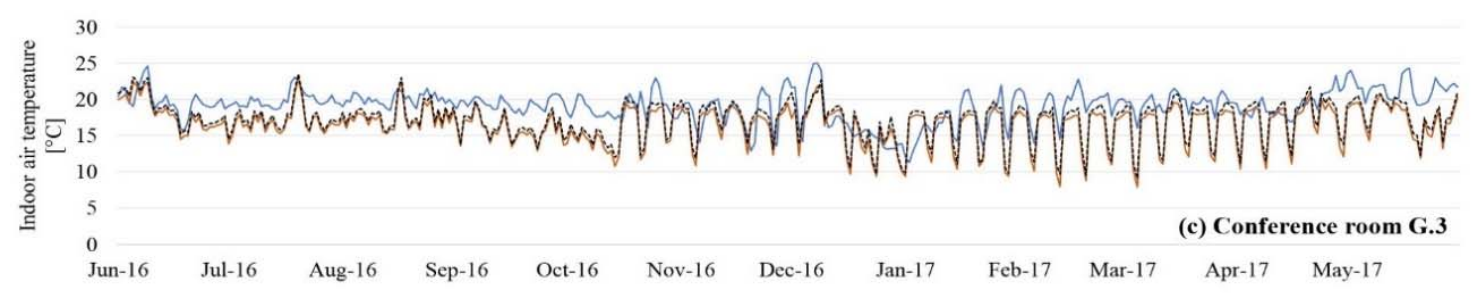

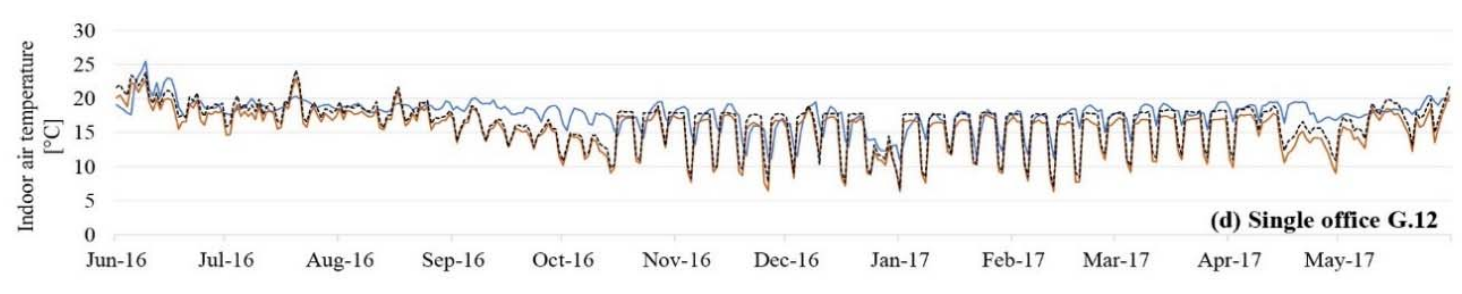
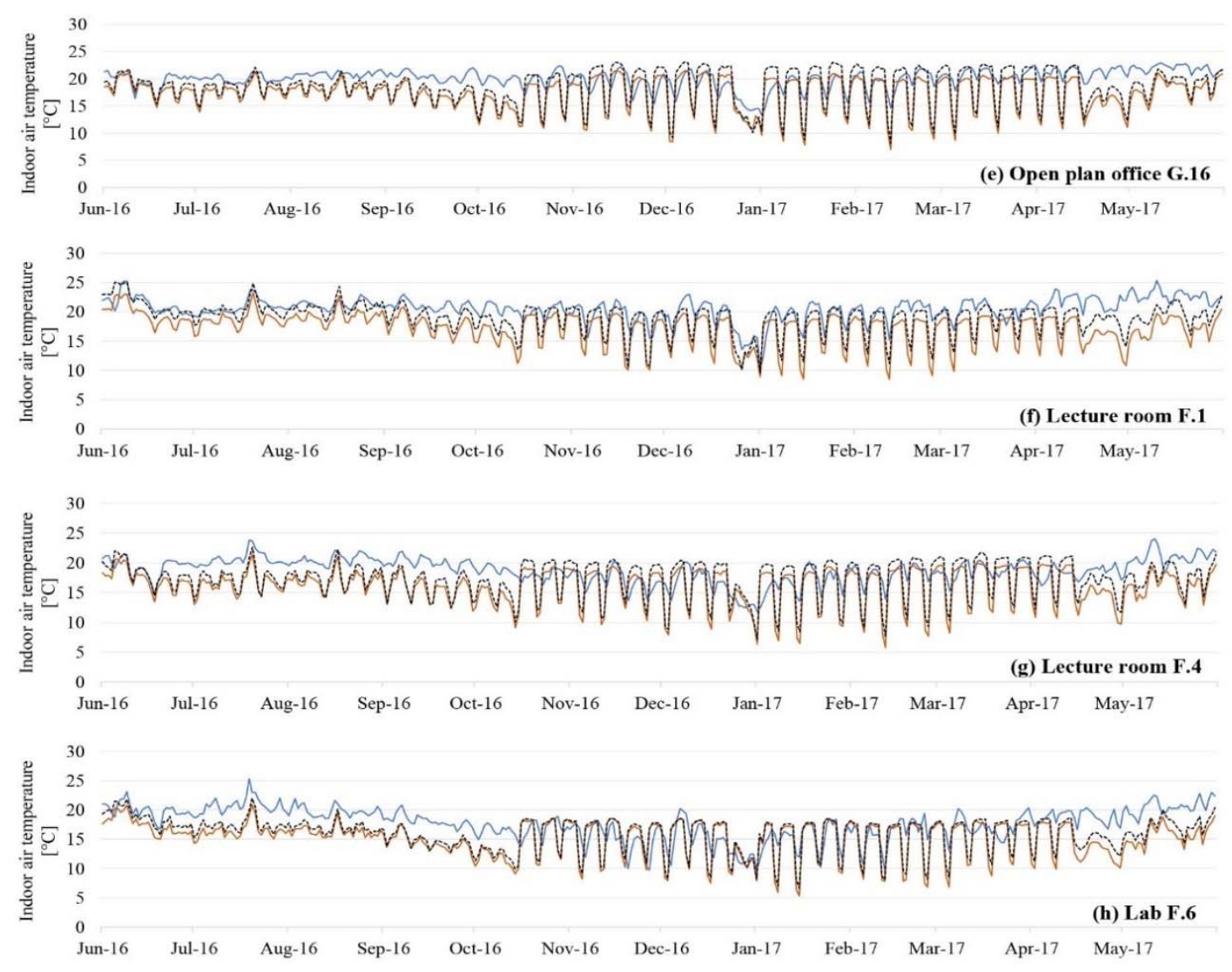

Figure 10 Daily averaged room temperature plot for measured and simulated hourly data with residuals 
In Figure 11, an example of a weekly comparison of hourly simulated and measured data for the four seasons is given for one room, 'Single office G.0'. The criteria for Cv(RMSE) $)_{\text {Hourly }}$ and NMBE Hourly values of $30 \%$ and $10 \%$ are satisfied with these resultant profiles. However, a major finding from these results emerges that with such old non-domestic building ( $>35$ yrs.), it is difficult to achieve higher accuracies even with automated calibration at hourly levels with regard to the indoor thermal environment.
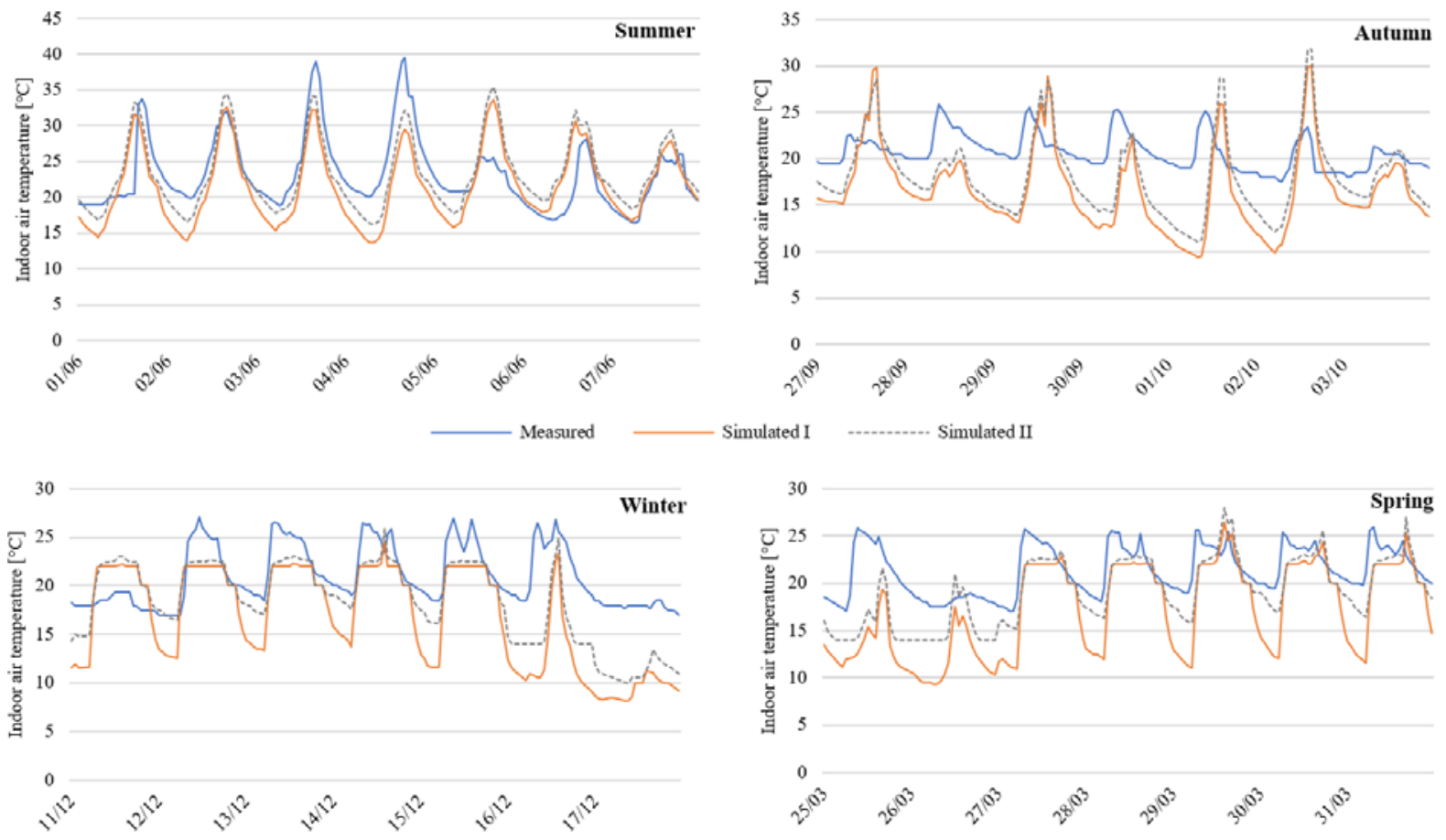

Figure 11 Weekly comparison of hourly measured and simulated data (e.g. Single office G.0)

\subsubsection{Additional validation}

To ensure the accuracy of the calibrated model, an additional validation was conducted by comparing the energy consumption and indoor temperature data that was measured in the actual building for a subsequent year (May 2017 - April 2018) against that predicted by the model. Literature has also highlighted that a major source of uncertainty in calibrated model results is weather dataset, which can have inaccuracies and discrepancies [88]; therefore, the weather data set was updated using measured data from the NUI Galway local weather station from May 2017 to April 2018 [70]. All other input parameters in the model remained unchanged, assuming that the semester schedules were similar to the previous year.

The results of validation are presented in Table 12 , where $\mathrm{Cv}(\mathrm{RMSE})_{\text {Monthly }}$ for electricity consumption is $15.1 \%$, nearly satisfying the criteria, and for heating energy consumption it is $14.3 \%$ as compared to $9.0 \%$ in second-stage 
results. $\mathrm{Cv}(\mathrm{RMSE})_{\text {Hourly }}$ and $\mathrm{NMBE}_{\text {Hourly }}$ for indoor air temperature of all the representative zones also met the acceptance criteria indicating good calibration accuracy of the model compared to the second-stage results.

Table 12 Validation results against utility and temperature data of 2017-18

\begin{tabular}{|c|c|c|}
\hline & Cv(RMSE) Monthly $[\%]$ & NMBE $_{M o n t h l y}[\%]$ \\
\hline $\begin{array}{l}\text { Total Electricity } \\
\text { consumption }\end{array}$ & 15.1 & 3.5 \\
\hline $\begin{array}{l}\text { Heating energy } \\
\text { consumption }\end{array}$ & 14.3 & 0.9 \\
\hline Indoor air temperature & $\operatorname{Cv}(\text { RMSE) })_{\text {Hourly }}[\%]$ & NMBE Hourly $_{\text {[\%] }}$ \\
\hline Single Office (G.0) & 20.3 & 7.6 \\
\hline Single Office (G.1) & 23.1 & 3.1 \\
\hline Conference Room (G.3) & 24.6 & 9.9 \\
\hline Single Office (G.10) & 23.8 & 5.6 \\
\hline Single Office (G.12) & 26.7 & 4.8 \\
\hline Open plan office (G.14) & 24.1 & 10.0 \\
\hline Lecture room (F.1) & 18.2 & 7.4 \\
\hline Lecture room (F.4) & 24.2 & 6.1 \\
\hline $\mathrm{Lab}(\mathrm{F} .6)$ & 25.1 & 9.7 \\
\hline
\end{tabular}

\section{Conclusions and future work}

A greater impact on energy consumption and indoor temperature can be attributed to the occupant heating setpoint preferences, infiltration rates, occupant density and building thermo-physical properties as identified in the sensitivity analysis results using Morris method. Morris screening significantly reduced the computation time and required parameters for calibration from 51 to 25 . In this study, the automated calibration involved the use of simulation tools and genetic algorithm (NSGA-II) for optimisation. The purpose of this research was to present an application of a methodology that could be utilised for producing reliable calibrated models using automated methods for existing non-domestic buildings ( $>35$ yrs.) with limited measured data and high uncertainty. The multi-stage method of calibration allows to combine different types of datasets for calibration step by step. The predicted values in calibration results nearly met the acceptance criteria due to the reduced inconsistency in mapping occupant behaviour related inputs in simulations that are often very difficult to obtain accurately in real situations. It was also a result of deviation in thermo-physical properties of the building that may vary over a period in the existing buildings. The use of automated multi-stage calibration was preferred over manual iterative calibration approach, as it enabled the alteration of more than one parameter simultaneously and optimise among 25 parameter value constraint sets. It is important that (i) monthly energy consumption data is available for the initial stages of calibration, and (ii) hourly indoor environment data can be used for detailed calibration, to achieve better model accuracy making it suitable for development of models to be used for the evaluation of IEQ (e.g. thermal comfort and indoor air quality) along with energy consumption. The results also indicated that it is 
difficult to achieve higher calibration accuracies for indoor temperatures of buildings with a large number of zones in partially-retrofitted building. Thus, highlighting the performance of partial-retrofit applications guiding further research into retrofit decision-making. The model data incorporates information from an occupied building; therefore, this approach is applicable to existing occupied buildings. Additional validation of the model for a subsequent year by only updating the weather dataset to that measured and independent measured data proved the accuracy of the calibrated model.

This study was an initial step in calibrating the building energy model of an existing non-domestic building with uncertainties using monthly utility and hourly indoor temperature data. Making decisions on potential retrofit solutions based on non-calibrated models may lead to uncertainties, and potentially significant inaccuracies, in the thermal and energy performance of the existing buildings. Future research would quantify the effects of retrofit decision making using the calibrated building energy model on the indoor comfort parameters, energy efficiency and life-cycle costs of the building [89]. Another sampling method can be employed during sensitivity analysis for improving the accuracy of the results. Higher frequency data is preferred for energy consumption that could provide improved accuracy in the first-stage calibration and it was limitation in this case. The calibration methodology may also be tested on buildings with higher complexity in heating, ventilation and air conditioning (HVAC) systems that needs further research.

\section{Conflict of Interest}

The authors declared that they have no conflicts of interest to this work.

\section{Acknowledgements}

The authors would like to acknowledge financial support from Science Foundation Ireland (Grant No. 13/CDA/2200) and European Union's Horizon 2020 Built2Spec project (Grant No. 637221). The authors would also like to thank all the participants of survey from the case study building and the Buildings \& Estates Office at NUI Galway for facilitating the data required in this research. The authors would also like to acknowledge Prof Corey Griffin for his input into the early stages of model development.

\section{References}

[1] BPIE, "Factsheet - 97\% of buildings in the EU need to be upgraded," Buildings Performance Institute Europe, Brussels, 2017. 
[2] I. Artola, K. Rademaekers, R. Williams, and J. Yearwood, "Boosting Building Renovation: What potential and value for Europe?," European Union, Brussels, 2016.

[3] N. Baker, The Handbook of Sustainable Refurbishment: Non-Domestic Buildings. London: Earthscan, 2009.

[4] Ö. Duran, S. C. Taylor, and K. J. Lomas, "Evaluation of refurbishment strategies for post-war office buildings,” Build. Simul. Conf., no. Odpm 2012, pp. 138-145, 2015.

[5] BPIE, “Europe's Buildings Under the Microscope: A country-by-country review of the energy performance of buildings,” Buildings Performance Institute Europe, Brussels, 2011.

[6] T. Boermans, K. Bettgenhäuser, M. Offerman, and S. Schimschar, "Renovation tracks for Europe up to 2050,” EURIMA, Germany, 2012.

[7] P. Raftery, M. Keane, and J. O’Donnell, “Calibrating whole building energy models: An evidence-based methodology,” Energy Build., vol. 43, no. 9, pp. 2356-2364, 2011.

[8] Y. Heo, R. Choudhary, and G. A. Augenbroe, "Calibration of building energy models for retrofit analysis under uncertainty,” Energy Build., vol. 47, pp. 550-560, 2012.

[9] S. Zuhaib, R. Manton, M. Hajdukiewicz, M. Keane, and J. Goggins, “Attitudes and approaches of Irish retrofit industry professionals towards achieving nearly zero-energy buildings," Int. J. Build. Pathol. Adapt., vol. 35, no. 1, 2017.

[10] ASHRAE, “Standard 209-2018- Energy Simulation Aided Design for Buildings except Low-Rise Residential Buildings (ANSI Approved)," American Society of Heating, Refrigerating and Airconditioning Engineers, Atlanta, GA, 2018.

[11] J. Sousa, "Energy Simulation Software for Buildings: Review and Comparison," in Information Technology for Energy Applications, 2012, pp. 6-7.

[12] D. B. Crawley and J. W. Hand, "Contrasting the capabilities of building energy performance simulation programs," Build. Environ., vol. 43, pp. 661-673, 2008.

[13] S. Attia, L. Beltrán, A. De Herde, and J. Hensen, “Architect Friendly: a Comparison of Ten Different Building Performance Simulation Tools," in Eleventh International IBPSA Conference, 2009, pp. 1-8.

[14] S. H. Lee, T. Hong, M. A. Piette, and S. C. Taylor-Lange, "Energy retrofit analysis toolkits for commercial buildings: A review,” Energy, vol. 89, pp. 1087-1100, 2015. 
[15] W. Tian and R. Choudhary, “A probabilistic energy model for non-domestic building sectors applied to analysis of school buildings in greater London,” Energy Build., vol. 54, pp. 1-11, 2012.

[16] J. Reiss, "Energy retrofitting of school buildings to achieve plus energy and 3-litre building standards," Energy Procedia, vol. 48, pp. 1503-1511, 2014.

[17] F. Ascione, N. Bianco, R. F. De Masi, G. M. Mauro, and G. P. Vanoli, "Energy retrofit of educational buildings: Transient energy simulations, model calibration and multi-objective optimization towards nearly zero-energy performance,” Energy Build., vol. 144, pp. 303-319, 2017.

[18] D. B. Crawley et al., "EnergyPlus: Energy Simulation Program,” ASHRAE J., vol. 42, no. 4, pp. 49-56, 2000 .

[19] D. B. Crawley et al., "EnergyPlus: Creating a new-generation building energy simulation program," Energy Build., vol. 33, no. 4, pp. 319-331, 2001.

[20] K. P. Lam, J. Zhao, B. E. Ydstie, J. Wirick, M. Qi, and J. Park, “An Energyplus Whole Building Energy Model Calibration Method for Office Buildings Using Occupant Behavior Data Mining and Emprirical Data,” in 2014 ASHRAE/IBPSA-USA Building Simulation Conference, 2014, pp. 160-167.

[21] F. Roberti, U. F. Oberegger, and A. Gasparella, "Calibrating historic building energy models to hourly indoor air and surface temperatures: Methodology and case study,” Energy Build., vol. 108, pp. 236$243,2015$.

[22] K. Sun, T. Hong, S. C. Taylor-Lange, and M. A. Piette, “A pattern-based automated approach to building energy model calibration,” Appl. Energy, vol. 165, pp. 214-224, 2016.

[23] E. M. Ryan and T. F. Sanquist, "Validation of building energy modeling tools under idealized and realistic conditions," Energy Build., vol. 47, pp. 375-382, 2012.

[24] A. Chong, W. Xu, and K. P. Lam, "Uncertainty analysis in building energy simulation: A practical approach,” Proc. BS2015 14th Conf. Int. Build. Perform. Simul. Assoc., pp. 2796-2803, 2015.

[25] Y. Heo, "Bayesian Calibration of Building Energy Models for Energy Retrofit Decision-Making under Uncertainty," Geogia Institute of Technoloy, 2011.

[26] Y. Heo, G. Augenbroe, D. Graziano, R. T. Muehleisen, and L. Guzowski, “Scalable methodology for large scale building energy improvement: Relevance of calibration in model-based retrofit analysis," Build. Environ., vol. 87, pp. 342-350, 2015. 
[27] S. Bertagnolio, "Evidence Based Model Calibration for Efficient Building Energy Services- PhD thesis," University of Liège, 2012.

[28] M. H. Kristensen and S. Petersen, "Choosing the appropriate sensitivity analysis method for building energy model-based investigations," Energy Build., vol. 130, pp. 166-176, 2016.

[29] T. Yang, Y. Pan, J. Mao, Y. Wang, and Z. Huang, "An automated optimization method for calibrating building energy simulation models with measured data: Orientation and a case study," Appl. Energy, vol. 179, pp. 1220-1231, 2016.

[30] M. Rasouli, G. Ge, C. J. Simonson, and R. W. Besant, "Uncertainties in energy and economic performance of HVAC systems and energy recovery ventilators due to uncertainties in building and HVAC parameters," Appl. Therm. Eng., vol. 50, no. 1, pp. 732-742, 2013.

[31] S. Ø. Jensen, "Validation of building energy simulation programs: a methodology," Energy Build., vol. 22, no. 2, pp. 133-144, 1995.

[32] F. Domínguez-Muñoz, J. M. Cejudo-López, and A. Carrillo-Andrés, "Uncertainty in peak cooling load calculations," Energy Build., vol. 42, no. 7, pp. 1010-1018, 2010.

[33] C. J. Hopfe and J. L. M. Hensen, "Uncertainty analysis in building performance simulation for design support," Energy Build., vol. 43, no. 10, pp. 2798-2805, 2011.

[34] W. Tian and P. De Wilde, "Uncertainty and sensitivity analysis of building performance using probabilistic climate projections: A UK case study,” Autom. Constr., vol. 20, no. 8, pp. 1096-1109, 2011.

[35] D. Garcia Sanchez, B. Lacarrière, M. Musy, and B. Bourges, "Application of sensitivity analysis in building energy simulations: Combining first- and second-order elementary effects methods," Energy Build., vol. 68, no. PART C, pp. 741-750, 2014.

[36] H. J. Moon, "Uncertainty analysis in mould spore transportation and its application in an existing building," Indoor Built Environ., vol. 19, no. 3, pp. 355-365, 2010.

[37] Y. Heo, "Bayesian Calibration of Building Energy Models for Energy Retrofit Decision-Making under Uncertainty - PhD thesis,” Geogia Institute of Technoloy, 2011.

[38] H. Shen and A. Tzempelikos, "Sensitivity analysis on daylighting and energy performance of perimeter offices with automated shading,” Build. Environ., vol. 59, pp. 303-314, 2013. 
[39] C. Spitz, L. Mora, E. Wurtz, and A. Jay, "Practical application of uncertainty analysis and sensitivity analysis on an experimental house," Energy Build., vol. 55, pp. 459-470, 2012.

[40] W. Tian, "A review of sensitivity analysis methods in building energy analysis," Renew. Sustain. Energy Rev., vol. 20, pp. 411-419, 2013.

[41] S. Petersen and S. Svendsen, "Method and simulation program informed decisions in the early stages of building design,” Energy Build., vol. 42, no. 7, pp. 1113-1119, 2010.

[42] A. Saltelli, S. Tarantola, F. Campolongo, and M. Ratto, Sensitivity Analysis in Practice: A Guide to Assessing Scientific Models. John Wiley \& Sons, 2004.

[43] A. Saltelli et al., Global Sensitivity Analysis: The Primer. John Wiley \& Sons, 2008.

[44] A. Reddy, "Literature review on calibration of building energy simulation programs: Uses, problems, procedure, uncertainty, and tools," ASHRAE Trans., vol. 112, no. Part 1, pp. 226-240, 2006.

[45] ASHRAE, “ASHRAE Guideline 14- 2014: Measurement of Energy and Demand savings,” American Society of Heating, Refrigerating and Air-Conditioning Engineers, Atlanta, 2014.

[46] IMPVP, “International performance measurement and verification protocol: concepts and options for determining energy and water savings,” Efficiency Valuation Organisation, Oak Ridge, 2010.

[47] T. E. Bou-Saada and J. S. Haberl, "An improved procedure for developing calibrated hourly simulation models," in International Building Performance Simulation, 1995.

[48] D. Coakley, P. Raftery, and M. Keane, "A review of methods to match building energy simulation models to measured data," Renew. Sustain. Energy Rev., vol. 37, pp. 123-141, 2014.

[49] V. Monetti, E. Davin, E. Fabrizio, P. André, and M. Filippi, "Calibration of building energy simulation models based on optimization: A case study,” Energy Procedia, vol. 78, pp. 2971-2976, 2015.

[50] C. Andrade-Cabrera, W. J. N. Turner, D. Burke, O. Neu, and D. P. Finn, "Lumped Parameter Building Model Calibration using Particle Swarm Optimization," in 3rd Asia conference of International Building Performance Simulation Association (ASIM 2016), 2016.

[51] K. Deb, A. Pratap, S. Agarwal, and T. Meyarivan, “A fast and elitist multiobjective genetic algorithm: NSGA-II,” IEEE Trans. Evol. Comput., vol. 6, no. 2, pp. 182-197, 2002.

[52] S. Zuhaib, M. Hajdukiewicz, M. Keane, and J. Goggins, "Generic assessment of optimisation methods for performance based design of retrofitted building façades for nearly zero-energy buildings," in 10th 
Conference on Advanced Building Skins, 2015, pp. 425-433.

[53] K. Li, L. Pan, W. Xue, H. Jiang, and H. Mao, "Multi-Objective Optimization for Energy Performance Improvement of Residential Buildings: A Comparative Study,” Energies, vol. 10, no. 2, 2017.

[54] A. M. Rysanek and R. Choudhary, "Optimum building energy retrofits under technical and economic uncertainty," Energy Build., vol. 57, pp. 324-337, 2013.

[55] T. A. Reddy and I. Maor, "Procedures for Reconciling Computer-Calculated Results With Measured Energy Data ASHRAE Research Project 1051- RP,” Atlanta, 2006.

[56] E. Fabrizio and V. Monetti, "Methodologies and advancements in the calibration of building energy models," Energies, vol. 8, no. 4, pp. 2548-2574, 2015.

[57] E. Azar and C. C. Menassa, "A comprehensive analysis of the impact of occupancy parameters in energy simulation of office buildings," Energy Build., vol. 55, pp. 841-853, 2012.

[58] S. Zuhaib, R. Manton, C. Griffin, M. Hajdukiewicz, M. Keane, and J. Goggins, “An Indoor Environmental Quality (IEQ) assessment of a partially-retrofitted university building,” Build. Environ., vol. 139, no. May, pp. 69-85, 2018.

[59] R. Guglielmetti, D. Macumber, and N. Long, “OpenStudio: An Open Source Integrated Analysis Platform,” 12th Conf. Int. Build. Perform. Simul. Assoc., no. December, pp. 442-449, 2011.

[60] K. Menberg, Y. Heo, and R. Choudhary, "Sensitivity analysis methods for building energy models: Comparing computational costs and extractable information,” Energy Build., vol. 133, pp. 433-445, 2016.

[61] P. Heiselberg, H. Brohus, A. Hesselholt, H. Rasmussen, E. Seinre, and S. Thomas, “Application of sensitivity analysis in design of sustainable buildings," Renew. Energy, vol. 34, no. 9, pp. 2030-2036, 2009.

[62] R. Ghanem, H. Owhadi, and D. Higdon, Handbook of uncertainty quantification. Los Angeles: Springer International Publishing, 2017.

[63] Y. Zhang, "Use jeplus as an efficient building design optimisation tool," in CIBSE ASHRAE Technical Symposium, 2012.

[64] S. Gotshall and B. Rylander, "Optimal population size and the genetic algorithm," Proc. Genet. Evol. Comput. Conf., pp. 1-5, 2000. 
[65] A. Cacabelos, P. Eguía, L. Febrero, and E. Granada, "Development of a new multi-stage building energy model calibration methodology and validation in a public library,” Energy Build., vol. 146, pp. $182-199,2017$.

[66] M. Royapoor and T. Roskilly, "Building model calibration using energy and environmental data," Energy Build., vol. 94, pp. 109-120, 2015.

[67] ASHRAE, “ANSI/ASHRAE 55:2013 Thermal Environmental Conditions for Human Occupancy,” American Society of Heating, Refrigerating and Air-Conditioning Engineers, Atlanta, GA, 2013.

[68] LBNL, "Standby Power : Data- Summary Table," 2007. [Online]. Available: http://standby.lbl.gov/summary-table.html. [Accessed: 23-Oct-2017].

[69] M. A. Carolina, A. Cripps, D. Bouchlaghem, and R. Buswell, "Benchmarking small power energy consumption in UK office buildings : a review of data published in CIBSE guide F," Build. Serv. Eng. Res. Technol., vol. 34, no. 1, pp. 73-86, 2013.

[70] NUIG, "NUIG weather station," 2017. [Online]. Available: http://www.nuigalway.ie/iruse/weather.html. [Accessed: 08-Sep-2017].

[71] V. Garg, J. Mathur, T. Surekha, and A. Bhatia, Building Energy Simulation: A Workbook Using DesignBuilder. CRC Press, Taylor and Francis, 2017.

[72] M. D. Morris, "Factorial Sampling Plans for Preliminary Copmputational Experiments,” Technometrics, vol. 33, no. 2, pp. 161-174, 1991.

[73] I. Macdonald, "Quantifying the Effects of Uncertainty in Building Simulation- PhD thesis," University of Strathclyde, 2002.

[74] K. Menberg, Y. Heo, G. Augenbroe, and R. Choudhary, "New extension of Morris method for sensitivity analysis of Building Energy Models," in IBPSA Building Simulation 2013, 2013.

[75] G. Calleja Rodríguez, A. Carrillo Andrés, F. Domínguez Muñoz, J. M. Cejudo López, and Y. Zhang, “Uncertainties and sensitivity analysis in building energy simulation using macroparameters," Energy Build., vol. 67, pp. 79-87, 2013.

[76] B. Eisenhower, Z. O’Neill, V. A. Fonoberov, and I. Mezic, "Uncertainty and sensitivity decomposition of building energy models," J. Build. Perform. Simul., vol. 5, no. 3, pp. 171-184, 2012.

[77] ASHRAE, “ASHRAE Handbook of Fundamentals (SI)," American Society of Heating, Refrigerating 
and Air-Conditioning Engineers, Atlanta, 2009.

[78] C. J. Hopfe, "Uncertainty and sensitivity analysis in building performance simulation for decision support and design optimization - PhD thesis," Technische Universiteit Eindhoven, 2009.

[79] D. Coakley, "Calibration of Detailed Building Energy Simulation Models to Measured Data using Uncertainty Analysis- PhD thesis,” National University of Ireland, 2014.

[80] LBNL, "EnergyPlus: Auxiliary Programs," Lawrence Berkeley National Laboratory, California, 2017.

[81] CEN, “I.S. EN 13779:2007 - Ventilation for Non-Residential Buildings- Performance Requirements for Ventilation and Room- Conditioning Systems," European Commitee for Standardization, Brussels, 2007.

[82] CEN, "EN-15251: Indoor environemntal input parameters for design and assessment of energy performance of buildings adressing indoor air quality, thermal environment, lighting and acoustics," European Commitee for Standardization, Brussels, 2007.

[83] ASHRAE, “ASHRAE Standard 90.1- Energy Standard for Buildings Except Low-Rise Residential Buildings,” American Society of Heating, Refrigerating, and Air-Conditioning Engineers, 2016.

[84] F. Campolongo, A. Saltelli, and J. Cariboni, "From screening to quantitative sensitivity analysis. A unified approach," Comput. Phys. Commun., vol. 182, no. 4, pp. 978-988, 2011.

[85] CEN, "EN 15251: Indoor environmental input parameters for design and assessment of energy performance of buildings-addressing indoor air quality, thermal environment, lighting and acoustics," Brussels, 2012.

[86] ASHRAE, "ASHRAE Standard 140-2017 Standard Method of Test for the Evaluation of Building Energy Analysis Computer Programs (ANSI Approved),” Atlanta, GA, 2017.

[87] J. Branke, K. Deb, H. Dierolf, and M. Osswald, "Finding knees in multi-objective optimization," in International Conference on Parallel Problem Solving from Nature, 2004, pp. 722-731.

[88] S. Erba, F. Causone, and R. Armani, "The effect of weather datasets on building energy simulation outputs,” Energy Procedia, vol. 134, pp. 545-554, 2017.

[89] Zuhaib S., Goggins J. “Assessing evidence-based single-step and staged deep-retrofit towards nearly zero-energy buildings (nZEB) using multi-objective optimisation”, Energy Efficiency, DOI: $10.1007 / \mathrm{s} 12053-019-09812-\mathrm{z}$ 